\title{
Diurnal and day-to-day characteristics of ambient particle mass size distributions from HR-ToF-AMS measurements at an urban site and a suburban site in Hong Kong
}

\author{
Berto Paul Lee ${ }^{1}$, Hao Wang ${ }^{2}$, and Chak Keung Chan ${ }^{1,2}$ \\ ${ }^{1}$ School of Energy and Environment, City University of Hong Kong, Hong Kong, China \\ ${ }^{2}$ Division of Environment, Hong Kong University of Science and Technology, Hong Kong, China \\ Correspondence to: Chak Keung Chan (chak.k.chan@ cityu.edu.hk)
}

Received: 22 February 2017 - Discussion started: 13 April 2017

Revised: 29 September 2017 - Accepted: 8 October 2017 - Published: 15 November 2017

\begin{abstract}
Mass-concentration-based particle size distributions measured by a high-resolution aerosol mass spectrometer were systematically analyzed to assess long and shortterm temporal characteristics of ambient particle size distributions sampled at a typical urban environment close to emission sources and a suburban coastal site representing a regional and local pollution receptor location in Hong Kong. Measured distributions were bimodal and deconvoluted into submodes, which were analyzed for day-to-day variations and diurnal variations.

Traffic and cooking emissions at the urban site contributed substantially to particle mass in both modes, while notable decreases in mass median diameters were limited to the morning rush hour. Inorganic particle components displayed varying diurnal behavior, including nocturnal nitrate formation and daytime photochemical formation evident in both modes. Suburban particle size distributions exhibited notable seasonal disparities with differing influence of local formation, particularly in spring and summer, and transport which dominated in the fall season leading to notably higher sulfate and organic accumulation-mode particle concentrations. Variations in particle mixing state were evaluated by comparison of interspecies mass median diameter trends at both measurement sites. Internal mixing was prevalent in the accumulation mode in spring at the urban site, while greater frequency of time periods with external mixing of particle populations comprising different fractions of organic constituents was observed in summer. At the suburban site, sulfate and nitrate in the accumulation mode more frequently exhibited differing particle size distributions in all seasons, signifying a greater extent of external mixing.
\end{abstract}

At the urban site, periods of greater submicron inorganic mass concentrations were more likely to be caused by increases in both Aitken- and accumulation-mode particle mass in summer, while at the suburban receptor location, organic and nitrate Aitken-mode particle mass contributed more regularly to higher total submicron species mass concentrations in most seasons (spring, summer, and winter).

\section{Introduction}

Apart from mass and chemical composition, the size distribution of fine particles represents a vital physical property with important implications for human health and environmental effects of ambient aerosols (Seinfeld and Pandis, 2006). Particle size relates directly to the aerodynamic properties, which govern the penetration and deposition of particles in the airways and lungs (Davidson et al., 2005) as well as the scattering and absorption of light that affect the radiative properties and hence ambient visibility (Ahlquist and Charlson, 1967; Bohren and Huffman, 1983; Charlson et al., 1991; Schwartz, 1996; Seinfeld and Pandis, 2006). Hygroscopic growth in response to changes in ambient humidity can alter particle light scattering properties (Seinfeld and Pandis, 2006; Köhler, 1936), and activation of condensation nuclei particles into cloud droplets depends on atmospheric conditions, chemical composition, mixing state, and the size and morphology of particles (Abbatt et al., 2005; Kerminen et al., 2012; Meng et al., 2014; Westervelt et al., 2013). 
Studies into the size distribution of ambient particulate matter in Hong Kong have been largely based on sizesegregated filter samples (Yao et al., 2007a; Zheng et al., 2008; Zhuang et al., 1999; Huang et al., 2014; Bian et al., 2014) and measurements by electrostatic classifier instruments (Cheung et al., 2015; Yao et al., 2007b) and were hence either limited in size resolution (offline filter samples) or chemical resolution (total particle count by classification). Most measurements in Hong Kong were conducted in suburban environments. Inorganic ammonium and sulfate were mainly found in fine-mode particles in condensation- and droplet-mode size ranges, while nitrate had strong coarsemode contributions (Zhuang et al., 1999). Seasonal differences were evident in solvent-extractable organics and trace metals, which were mainly found in $\mathrm{PM}_{0.5}$ particles in the wet season and winter, whereas in fall a shift to larger particles $(0.5-2.5 \mu \mathrm{m}$ fraction) indicated a possibly stronger influence of aged particle components in the transition period of the Asian monsoon (Zheng et al., 2008). Size distributions acquired by a fast mobility particle sizer at the suburban HKUST supersite were investigated more recently to study the formation and accumulation of ultrafine particles under different air flow regimes. Particle number concentration enhancements during the day were attributed to secondary formation, while evening and nighttime peaks were thought to be related to transport of aged aerosols from upwind locations. Nucleation-mode particle peaks were often observed in fall and related to regional pollution influence (Cheung et al., 2015). New particle formation events at the same site occurred as single- and two-stage growth processes with organics and sulfuric acid contributing mainly to first-stage growth in the daytime while nighttime second-stage growth was attributed to ammonium nitrate and organics. Particle size growth into the diameter range of cloud condensation nuclei was typically only achieved with the second growth stage (Man et al., 2015).

Investigations into particle size distributions in urban areas of Hong Kong are even scarcer. Yao et al. (2007b) studied the properties and behavior of particles in vehicle plumes and reported a competing process between ambient background particles and fresh soot particles in the condensation of gaseous precursors and a dependency on temperature with bimodal volume size distributions observed at lower ambient temperatures and unimodal distributions in the lower accumulation size range at higher ambient temperatures.

The Aerodyne aerosol mass spectrometer (AMS; Canagaratna et al., 2007) is widely used to determine the chemical composition of major organic and inorganic components of non-refractory submicron particulate matter (NR$\mathrm{PM}_{1}$ ). In contrast to most traditional aerosol sizing instruments, the AMS is capable of resolving main chemical constituents within size distributions through analysis of particle flight times and particle ensemble mass spectra (Canagaratna et al., 2007; Jayne et al., 2000; Jimenez et al., 2003; Rupakheti et al., 2005) and thus yields valuable additional information on differences in composition of submicron particles with the gross of particle mass in the Aitken-mode range $\left(D_{\mathrm{p}} \sim 10-100 \mathrm{~nm}\right)$ and the accumulation-mode range $\left(D_{\mathrm{p}} \sim 100-1000 \mathrm{~nm}\right)$ covered by the AMS. Thus far most studies employing ambient size distribution data from AMS measurements investigated longer time period averages, i.e., campaign averages (Salcedo et al., 2006; Sun et al., 2009; Aiken et al., 2009; Huang et al., 2010; Takegawa et al., 2009; Saarikoski et al., 2012; Li et al., 2015) or specific time periods of interest (Elser et al., 2016; Lee et al., 2013). Mohr et al. (2012) separated organic particle mass size distributions by periods of dominant influence of different organic aerosol factors resolved using positive matrix factorization (PMF) to study the properties of mass size distributions in relation to organic aerosol composition. The 3-D factorization technique is an extension of traditional AMS PMF analysis on organic aerosol to obtain estimates on the size distributions of organic aerosol factors, however, under the assumption that factor size distributions remain invariant over the measurement period (Ulbrich et al., 2012).

The temporal evolution of species-specific size distributions are mostly discussed qualitatively (Drewnick et al., 2005) and only few studies have evaluated temporal trends in mass size distributions in greater detail. Particle nucleation and subsequent growth events were investigated in Pittsburgh using size data from an AMS and two scanning mobility particle sizers as well as various gaseous pollutant instruments and meteorological information. The AMS mass size distributions were evaluated quantitatively using the time series of binned particle concentrations generated from the grouping of raw data into wider size bins to represent different stages in the particle growth process (Zhang et al., 2004). The same method was employed to evaluate contributions of ultrafine-mode and accumulation-mode particles to total organic particle mass (Zhang et al., 2005) by summation of size bins in the ranges of 30-100 and 100-1000 nm. The authors also explored diurnal changes in size distributions of particle species by averaging over $3 \mathrm{~h}$ periods in the morning (06:00-09:00 LT, UTC - 5) and afternoon (13:0016:00). Sun et al. (2011) present a qualitative discussion of diurnal variations in the mass size distributions of the $m / z 44$, $m / z 57$, and derived $\mathrm{C}_{4} \mathrm{H}_{9}^{+}$ion signals from measurements at an urban site in New York. Similarly, Setyan et al. (2012) examined diurnal changes in the mass size distributions of organics and sulfate qualitatively and used binned concentrations (40-120, 120-200, and 200-800 nm) in their quantitative analysis to study the evolution of particle chemistry in new particle formation and growth events.

In this work, we introduce a systematic approach of assessing temporal variations in AMS mass-based particle size distributions from hourly diurnal variations to day-to-day trends based on a $24 \mathrm{~h}$ average to utilize two key instrumental advantages, i.e., species segregation and high time resolution, to obtain a more detailed and quantitative understanding of the variabilities in ambient particle mass size distributions 
and to provide an additional dimension to standard AMS data analysis techniques. In this context, we present a detailed discussion of particle size data from high-resolution time-of-flight AMS (HR-ToF-AMS) measurements during two field campaigns in Hong Kong in both urban and suburban environments. We aim to evaluate characteristic recurrent changes in size distribution as well as longer term trends in different seasons by analyzing day-to-day variations and diurnal variations in size distributions of submicron organics, sulfate, and nitrate particle mass. The two contrasting sites represent a typical urban source environment (inner city, roadside station) close to primary emission sources and a suburban location (coastal, HKUST supersite) that is largely a downwind receptor of varying amounts of local urban, regional, and long-range-transported pollutants (Li et al., 2015; Huang et al., 2014).

\section{Methodology}

\subsection{Field campaigns}

Sampling of ambient NR-PM 1 was carried out using an Aerodyne HR-ToF-AMS at the HKUST air quality supersite covering four seasons between May 2011 and February 2012 (spring: May 2011; summer: September 2011; fall: November and December 2011; winter: February 2012). The HKUST supersite is located on the campus of the Hong Kong University of Science and Technology $\left(22^{\circ} 20^{\prime} \mathrm{N}, 114^{\circ} 16^{\prime} \mathrm{E}\right)$, on the east coast of Hong Kong in a suburban area with few primary emission sources in the immediate vicinity. Sampled air was drawn from the rooftop of a pump house building at an approximate height of $25 \mathrm{~m}$ above ground level. For detailed descriptions of the experimental setup, operating conditions, data treatment, and overall species composition, we refer the reader to previous publications (Lee et al., 2013; Li et al., 2015, 2013). A further sampling campaign took place between spring 2013 (March to May 2013) and summer 2013 (May to July 2013) at an inner-city urban location on the densely populated and built-up Kowloon peninsula. Measurements were conducted next to the roadside air quality monitoring station (AQMS) operated by the Environmental Protection Department (EPD) of the Hong Kong SAR, China, government in the Mong Kok (MK) district on a pedestrian crossing at a major road junction. Sampled air was drawn from a height of $3 \mathrm{~m}$ above ground level. A comprehensive analysis of trends in species concentration and composition identified in this urban campaign has been presented previously (Lee et al., 2015). In both campaigns, particles were sampled through a $\mathrm{PM}_{2.5}$ cyclone at a flow rate of 16.67 $\mathrm{L} \mathrm{min}^{-1}$ into a sampling port from which $0.08 \mathrm{~L} \mathrm{~min}^{-1}$ was drawn by the AMS and the remainder drawn by cosampling instruments and an auxiliary pump. Sample air for the AMS passed through a $1 \mathrm{~m}$ long diffusion dryer (BMI, San Francisco CA, USA) filled with silica gel to remove bulk gas- and particle-phase water. Additional data from various collocated instruments including meteorological data (wind, temperature, relative humidity, solar irradiation), volatile organic compounds (VOCs), and standard trace gases such as $\mathrm{NO}_{x}, \mathrm{SO}_{2}$, and $\mathrm{O}_{3}$ were available.

AMS data were treated according to general AMS data treatment principles (DeCarlo et al., 2006; Jimenez et al., 2003) with standard software packages (SQUIRREL, PIKA). Analysis of the unit-mass resolution mass spectra yielded non-refractory submicron particle species concentrations of major inorganic constituents $\left(\mathrm{SO}_{4}, \mathrm{NO}_{3}, \mathrm{NH}_{4}, \mathrm{Chl}\right)$ and total organics at a base time resolution of $10 \mathrm{~min}$. PMF was used to deconvolute high-resolution organic mass spectra acquired at 10 min time resolution following recommended PMF guidelines for AMS data (Zhang et al., 2011) with the AMS PMF analysis toolkit (Ulbrich et al., 2009). At the urban Mong Kok site, six organic aerosol (OA) factors were identified encompassing three secondary organic aerosol (SOA) and three primary organic aerosol (POA) factors of which one was attributed to traffic emissions and two to cooking activities (Lee et al., 2015). Similarly, four factors were obtained from analysis of the urban HKUST site dataset with two SOA factors and two POA factors, the latter related to traffic and cooking ( $\mathrm{Li}$ et al., 2015). Further details on the treatment of AMS size distribution data from both sampling campaigns are provided in the following section.

\subsection{Data acquisition and treatment}

In both campaigns, mass-concentration-based size distributions in terms of vacuum-aerodynamic particle diameter $\left(\mathrm{d} M / \mathrm{d} \log D_{\text {va }}\right)$ were established by joint acquisition of particle time-of-flight (PToF) measurements and unit mass resolution mass spectra (V-mode) with alternation between modes every $20 \mathrm{~s}$ for 30 cycles amounting to $5 \mathrm{~min}$ of total sampling time. High-resolution mass spectra were acquired for the following $5 \mathrm{~min}$, and thus the overall raw data time resolution for each mode was equal to $10 \mathrm{~min}$. The total particle mass measured in the PToF mode was normalized to the $\mathrm{V}$-mode mass concentration of the same time step. Daily size distributions were generated by averaging over $24 \mathrm{~h}$ periods (from 00:00 to 23:59). Hourly diurnal size distributions were reconstructed by grouping size distributions within the same hour of the day and establishing representative size distributions based on average, median, and 25th and 75th percentile concentration values of each size bin (referred to as size distribution sets hereinafter).

At both sampling sites, the seasonally averaged AMS size distributions were bimodal (Lee et al., 2013, 2015; Li et al., 2015), with similar distributions having been observed in other AMS field studies in various parts of the world (Zhang et al., 2014, 2005; Sun et al., 2011; Huang et al., 2011; Aiken et al., 2009; Crippa et al., 2013; Docherty et al., 2011; Mohr et al., 2012). Multimodality of size distributions is typical for environments in which different sources or formation pro- 
cesses of particles play a role. Accordingly, such distributions can also be represented as sums of discrete lognormal distributions of the respective constituting submodes (John, 2011).

The measured bimodal size distributions in this work were deconvoluted by fitting two log-normal distributed modes, including one closer to the Aitken size range (mode diameter $\sim 100 \mathrm{~nm}$ ) and one in the accumulation size range (mode diameter $\sim 500 \mathrm{~nm}$ ) employing the Levenberg-Marquardt algorithm (Gill et al., 1981) as a nonlinear least squares fit to evaluate differences in trends and formation or transformation processes in the two size regimes. An example of a size distribution fit and associated parameters is depicted in Fig. S1 in the Supplement. Additional fit residual analyses were carried out in cases in which the Aitken mode only accounted for small parts $(<10 \%)$ of the total particle mass, and uncertainties in integrated-mode particle mass from the peak fitting were examined for all size distributions. Details are presented in the Supplement (Sect. S2). The smaller mode typically exhibited mode diameters in the range of $100-200 \mathrm{~nm}\left(D_{\mathrm{va}}\right)$ and is thus in the transition region between the Aitken and lower accumulation modes. For a clearer distinction from the larger mode, which unambiguously belonged to the accumulation size range, we opt to refer to the small mode as Aitken mode in this work. Mode diameter (i.e., mass median diameter, MMD), curve width (i.e., geometric standard deviation, GSD), and curve area (equivalent to particle mass concentration within the mode) are sufficient parameters to completely describe a lognormal distribution and these key variables are used in the following analysis on trends in the fitted species-specific size distributions of organics, nitrate, and sulfate from both HR-AMS sampling campaigns in Hong Kong. Particle diameters are discussed in terms of vacuum-aerodynamic diameter, with detailed discussions on properties and relationships to other size metrics available elsewhere (DeCarlo et al., 2004; Slowik et al., 2004). Further details on procedures of PToF data acquisition and size distribution averaging can be found in the Supplement (Sects. S1, S2). The sequence of main data treatment and analysis steps is shown in Fig. 1.

The transmission efficiency of the AMS aerodynamic lens is known to fall off below $\sim 100 \mathrm{~nm}$ and beyond $\sim 550 \mathrm{~nm}$ of vacuum-aerodynamic diameter (Liu et al., 2007; Takegawa et al., 2009; Zhang et al., 2004; Bahreini et al., 2008; Williams et al., 2013; Knote et al., 2011) and may bias measured particle mass and mode diameters, particularly in the accumulation mode towards lower values if significant particle mass fractions fall in the size region of $D_{\mathrm{va}}>550 \mathrm{~nm}$. In the Aitken-mode range, the effect of limited lens transmission is expected to be less substantial as particle volume (and hence particle mass) of Aitken-mode particles is much smaller. We discuss the effects of lens transmission briefly in Sect. 3.4. Delayed vaporization of particle components, e.g., under high mass loadings, can lead to small shifts towards larger mode diameters in AMS size distribu- tions (Docherty et al., 2015) and enhanced tails in the size distributions (Cross et al., 2009), which may lead to larger fit residuals at the trailing edges. Generally, the discussion of size distributions in this work should be viewed in the context of the instrumental capabilities and previously mentioned limitations of aerosol mass spectrometry. Therefore, the resolved Aitken and accumulation modes in this work reflect the apparent Aitken and accumulation modes within AMS-measurable particle mass size distributions.

\section{Results and discussion}

\subsection{Diurnal size distribution characteristics}

Diurnal species variations are predominantly discussed in terms of total mass concentration up to the size cut of the sampling inlet or the instrumental capability, e.g., total species concentrations in NR-PM 1 for AMS-based studies.

AMS mass-based size distributions can be utilized more systematically and complementary to standard AMS data analysis techniques by deconvoluting multimodal distributions into their constituting submodes and evaluating their variation and contribution to overall species concentration variations on a diurnal timescale. As previously mentioned, we examined size distributions reconstructed from the average, median, and 25th and 75th percentiles of hourly grouped size distributions, analogous to commonly reported AMS species diurnal variations, with quantitative analysis focusing on concentrations from the median dataset.

\subsubsection{Urban roadside NR-PM}

The urban roadside measurements took place between March and July 2013 covering two seasons (spring 2013: March to mid-May 2013; summer 2013: mid-May to July 2013) at a location dominated by the influence of primary emission sources. Organics were the major particulate species in NR-PM ${ }_{1}$, of which two-thirds were attributable to traffic and cooking sources. Anthropogenic gas-phase species, including various VOCs, $\mathrm{NO}_{x}, \mathrm{CO}$, and $\mathrm{SO}_{2}$, were continuously abundant as well (Lee et al., 2015; Sun et al., 2016). Particle size distributions at the urban site exhibited discernible diurnal trends, with Fig. 2 depicting the variations in (mass median) diameters of the lognormal fitted Aitken and accumulation modes, corresponding integrated peak areas representing the total mass accounted for by particles in each mode, the geometric standard deviation signifying the spread across particle sizes, and the total submicron mass $\left(\mathrm{NR}-\mathrm{PM}_{1}\right)$ diurnal variation for organics, sulfate, and nitrate based on AMS $\mathrm{V}$-mode data. Individual trends are discussed species-wise in the following. 


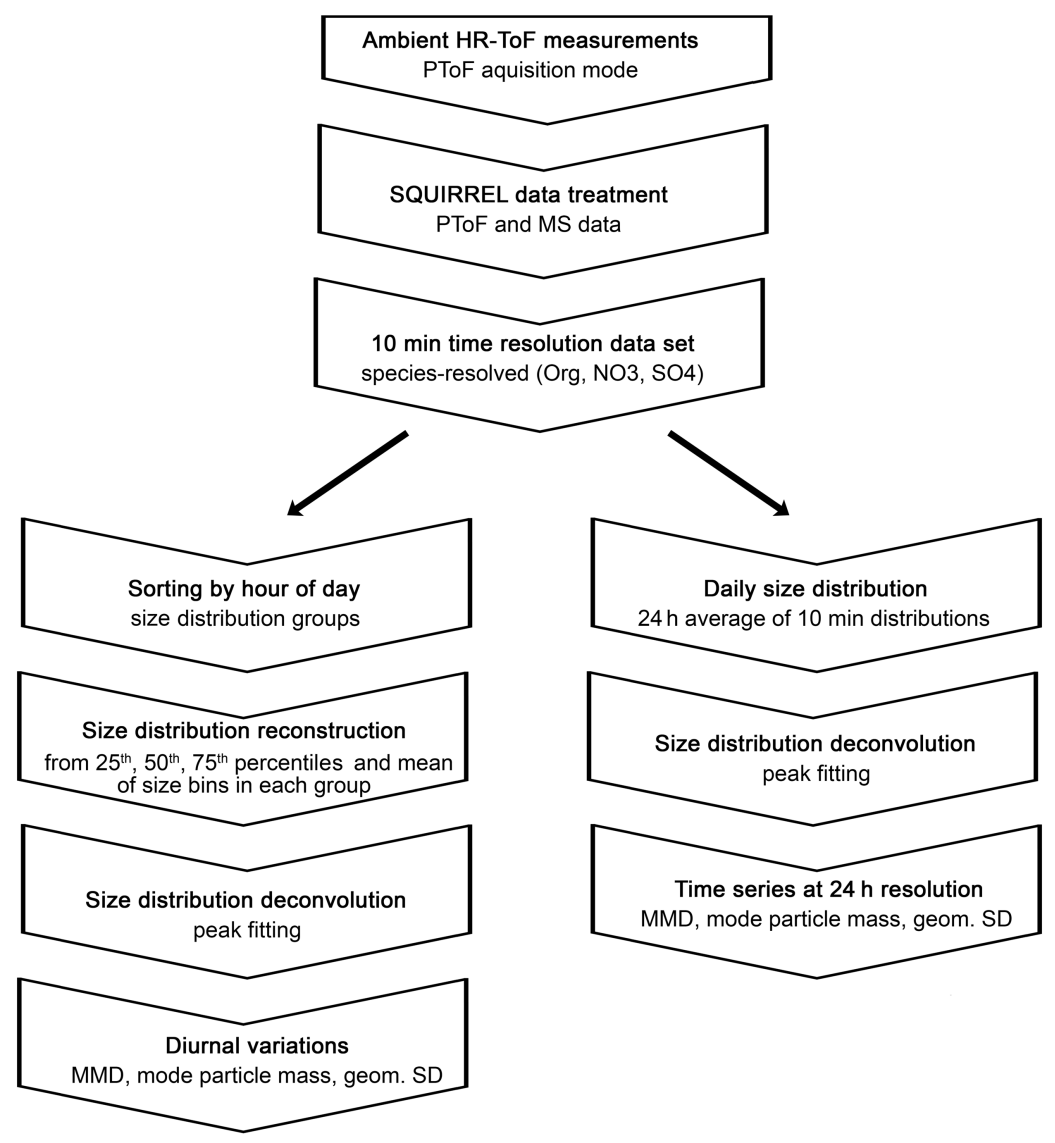

Figure 1. Flow chart of main data acquisition, data treatment, and data analysis procedures.

\section{Organics}

The diurnal variation in total Aitken- and accumulationmode particle mass both largely followed the same trend as total submicron organic mass (Fig. 2a, b), affirming that urban sources of organic particulate matter contributed substantially to PM mass across the covered size region. Mass concentrations in both modes were smallest during the night (00:00 to 06:00) and highest during lunch and dinner (12:00 to $14: 00,19: 00$ to $21: 00$ ), when the influence of organic aerosol from cooking (COA - cooking organic aerosol) and from traffic (HOA - hydrocarbon-like organic aerosol) was dominant (Lee et al., 2015). Trends in integrated-mode particle mass and MMDs were similar across all size distribution sets (Fig. S6 in the Supplement), confirming that they occurred persistently throughout the measurement period and making diurnal timescale processes the dominant factor in determining size characteristics of organic-containing particles at this urban roadside location.

Minimum Aitken-mode particle mass concentrations (median values) amounted to $2.3 \mu \mathrm{g} \mathrm{m}^{-3}$ in spring and $1.2 \mu \mathrm{g} \mathrm{m}^{-3}$ in summer, accounting for $28-38 \%$ of total submicron particulate mass, and were typically reached between 03:00 and 04:00. These concentrations represent the esti- mated urban background mass of Aitken-mode particles carried over from the daytime and not removed by gravitational settling, coagulation, or sweep-out as well as contributions from nighttime activity such as traffic, which remains continuous in the inner-city districts at night albeit at much lower vehicle numbers compared to the daytime.

Organic concentrations increased notably between 06:00 and 09:00 during the morning rush hour, with traffic-related constituents (HOA - hydrocarbon-like organic aerosol) accounting for the largest part (60\% in spring, $40 \%$ in summer) of this increase. In the Aitken mode, particle mass concentrations rose by $1.6 \mu \mathrm{g} \mathrm{m}^{-3}$ (spring) and $0.8 \mu \mathrm{g} \mathrm{m}^{-3}$ (summer) in the same time period. Assuming direct proportionality between the contribution of HOA to total submicron organic mass increase and the increase in particle mass in each submode, $0.9 \mu \mathrm{g} \mathrm{m}^{-3}$ (spring) and $0.3 \mu \mathrm{g} \mathrm{m}^{-3}$ (summer) of particle mass were estimated as traffic-related organic components in the Aitken mode. Significant changes were evident in the particle size metric (MMD) during the same time period, in which a consistent decrease of 20-30\% from about $170 \mathrm{~nm}$ (spring) or $160 \mathrm{~nm}$ (summer) to $130-140 \mathrm{~nm}$ (spring) or $120 \mathrm{~nm}$ (summer) was evident with the concurrent increase in road traffic. This combined shift to smaller particle size and increase in total particle mass denotes a strong 


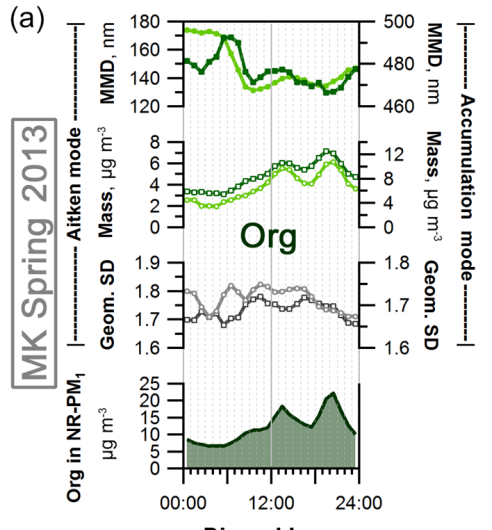

Diurnal hour

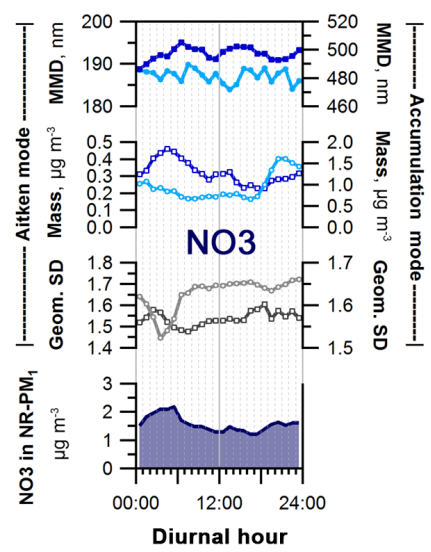

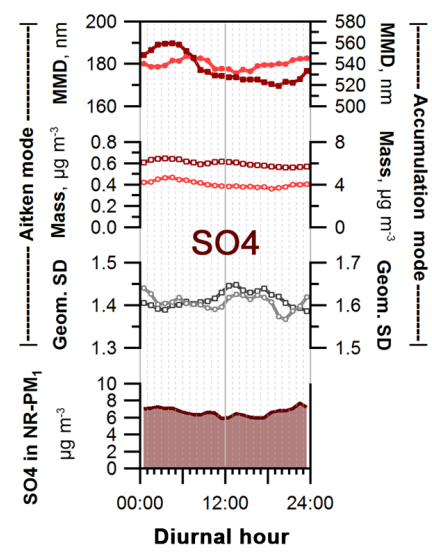

Gas-phase data

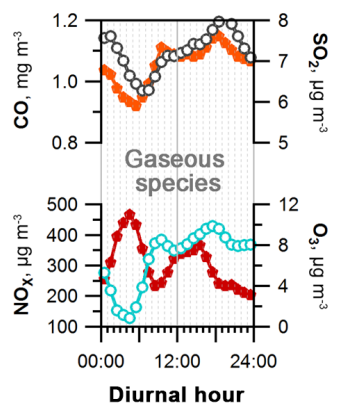

Size distribution data

Q- - -

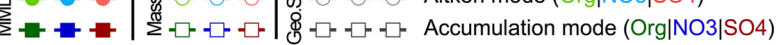
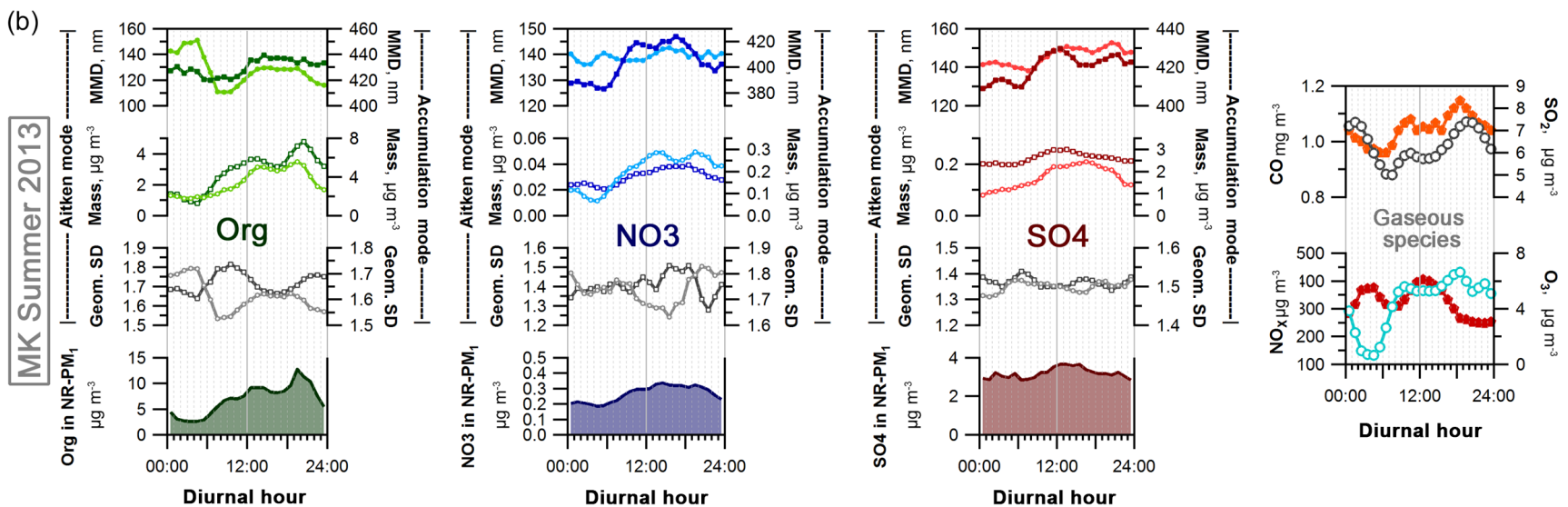

Figure 2. Diurnal variations in mode diameter (MMD), integrated-mode mass concentration, and width of the Aitken mode (lighter color) and accumulation mode (darker color) from bimodal peak fits of the bin-median reconstructed size distributions at the urban Mong Kok site, as well as V-mode AMS species concentrations (line with shaded background) for organics, nitrate, and sulfate (left to right) in (a) spring 2013 and (b) summer 2013. The right-most panels depict the median diurnal variations in relevant gas-phase pollutants $\left(\mathrm{O}_{3}, \mathrm{CO}, \mathrm{NO}_{x}, \mathrm{SO}_{2}\right)$ measured at the adjacent Mong Kok Air Quality Monitoring Site (MK AQMS).

increase in the total number concentrations of particles in the Aitken-mode range by at least a factor of 4-5 (assuming spherical particles and constant particle density) with significant additional contributions expected from elemental carbon particles and smaller Aitken-mode and nucleation-mode particles below the range of efficient particle transmission of the AMS inlet lens (Williams et al., 2013).

After 10:00, changes in submicron organic mass concentrations were dominated by variations in COA components. During the main mealtimes (12:00-14:00 and 19:0021:00) changes in organic submicron mass were almost entirely $(>80 \%$ ) caused by COA in both seasons (Table S4 in the Supplement) and daily maximum Aitken-mode particle mass concentrations typically occur during these hours (5.5-6.2 $\mu \mathrm{g} \mathrm{m}^{-3}$ in spring, 3.1-3.5 $\mu \mathrm{g} \mathrm{m}^{-3}$ in summer), with higher concentrations during the dinner period. Analogous to $\mathrm{HOA}$, considering proportionality between COA fractional contribution and submode particle mass increase, primary cooking emissions accounted for $1.7-1.8 \mu \mathrm{g} \mathrm{m}^{-3}$ of organic particle mass in the Aitken mode. Dinner in summer represents a notable exception, for which the estimated cookingrelated increase only amounted to $0.5 \mu \mathrm{g} \mathrm{m}^{-3}$. This is mainly due to specific local meteorological and geographical features owing to a greater frequency of easterly surface winds in the warmer season and the geographical distribution of cooking sources predominantly to the east of the sampling site (Sun et al., 2016; Lee et al., 2015), which led to considerably elevated Aitken-mode mass concentration throughout the day, including the late afternoon period and a correspondingly smaller additional increase during dinner time. The aforementioned effect is particularly evident in the diurnal trend of the Aitken-mode particle mass fraction among total organic submicron mass (Fig. 3a), which displayed a broad bell shape during the day in summer with nominal in- 
(a)

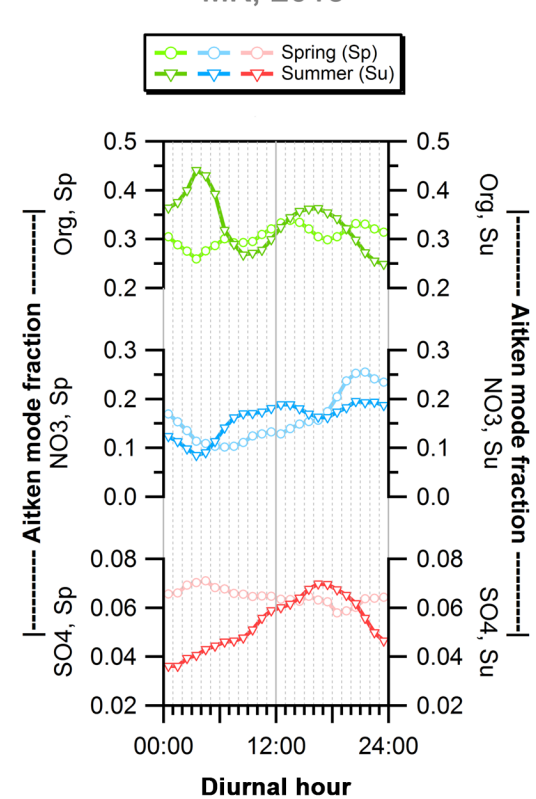

(b)

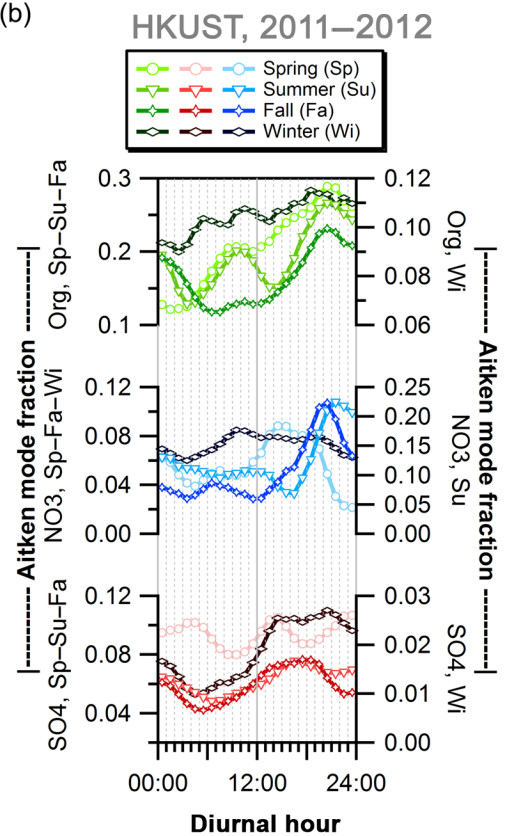

Figure 3. Diurnal variation in the fraction of Aitken-mode particle mass among total submicron species mass for organics (top), nitrate (middle), and sulfate (bottom) at (a) the urban Mong Kong site and (b) the suburban HKUST supersite in different seasons; based on concentrations from bin-median size distributions; seasons denoted by marker color and type of marker symbol.

creases of $9-10 \%$, whereas in spring the variation follows a double peak behavior with nominal increases of $4-5 \%$ during the mealtimes, which emphasizes the more intermittent behavior of cooking-related particle contributions in spring. Cooking emissions did not lead to conspicuous changes in the size-related distribution metrics, i.e., there were no obvious trends in particle diameters (MMDs) or distribution widths (GSDs) during the mealtime periods (Fig. 2a, b).

In the accumulation mode, organic particle mass during the night hours (00:00-06:00) was 2.5 times larger in spring $\left(5.5 \mu \mathrm{g} \mathrm{m}^{-3}\right)$ than in summer $\left(2.0 \mu \mathrm{g} \mathrm{m}^{-3}\right)$. The mass concentration increase during the morning rush hour was larger in summer $\left(\Delta M=3.9 \mu \mathrm{g} \mathrm{m}^{-3}\right)$ than in spring $(\Delta M=$ $3.0 \mu \mathrm{g} \mathrm{m}^{-3}$ ), which was mainly caused by daytime increases in SOA components in summer (Lee et al., 2015), and consequently led to a lower fractional rush hour increase in traffic-related organic constituents. Estimated particle mass contributions of traffic emissions in the accumulation mode amounted to $1.8 \mu \mathrm{g} \mathrm{m}^{-3}$ in spring and $1.6 \mu \mathrm{g} \mathrm{m}^{-3}$ in summer. In terms of particle size, the onset of the rush hour had little conspicuous effects on the accumulation mode without clear trends in MMDs in both seasons. In summer the shift to smaller MMDs was accompanied by a notable narrowing of the Aitken mode, whereas in spring Aitken-mode distribution widths remained largely stable throughout the day (Fig. 2a, b).

Maximum accumulation-mode particle concentrations during the mealtime hours reached $10.5-12.3 \mu \mathrm{g} \mathrm{m}^{-3}$ in spring and $6.0-7.4 \mu \mathrm{g} \mathrm{m}^{-3}$ in summer. Analogous to the
Aitken mode, estimated cooking-related particle contributions in the accumulation mode amounted to $2.0 \mu \mathrm{g} \mathrm{m}^{-3}$ (spring) and $1.0 \mu \mathrm{g} \mathrm{m}^{-3}$ (summer) during lunch and to $2.7 \mu \mathrm{g} \mathrm{m}^{-3}$ (spring) and $2.4 \mu \mathrm{g} \mathrm{m}^{-3}$ (summer) during dinner. Also, distribution widths (GSD) in the accumulation mode were not notably affected by cooking emissions. Seasonal differences were apparent in the MMDs of the accumulation mode. In spring, mode diameters remained largely constant $( \pm 10 \mathrm{~nm})$ apart from a subtle peak during the morning rush hour, indicative of minor condensational growth of traffic-related primary organics or rapidly formed secondary species. In summer, a consistent increase in particle size of $20 \mathrm{~nm}(\sim 5 \%)$ during the daytime points to particle growth through secondary formation as a governing factor.

Aitken-mode particles contributed larger fractions to the total increase in organic submicron particle mass during the rush hour and mealtimes in spring (33-56\%) than in summer (16-38\%). These differences were presumably due to seasonal meteorology and associated effects on the formation, accumulation, and dispersion of particles from primary emission sources, as source strengths and characteristics of road traffic and commercial cooking are unlikely to vary with seasons in the inner-city urban areas of Hong Kong. Ambient temperatures and solar irradiation differed substantially, with $7{ }^{\circ} \mathrm{C}$ higher average temperatures and 3 times higher integrated daily solar irradiation in summer compared to spring (Fig. S10e-f in the Supplement). Lower overall ambient temperatures enhance condensation of gas-phase emissions and particle nucleation and shift the gas-to-particle partitioning 
equilibrium of semi-volatile constituents towards the particle phase. We expect these volatility effects to be a main contributing factor, as sampling took place in the direct vicinity of the emission source, i.e., next to the road. Thus, potential impacts of physical effects such as enhanced near-ground mixing and dispersion through thermally induced convection in summer are expected to be of minor influence. Considering the previously discussed estimated traffic contributions during the rush hour, the seasonal difference in mass concentration was much more pronounced in the Aitken mode $\left(-67 \%, 0.6 \mu \mathrm{g} \mathrm{m}^{-3}\right)$ than the accumulation mode $(-12 \%$, $0.2 \mu \mathrm{g} \mathrm{m}^{-3}$ ), consistent with the expected stronger impact of reduced particle nucleation and reduced condensation of semi-volatile exhaust components on fresher, smaller particles in the warmer season.

Comparing different size distribution sets (Fig. S6 in the Supplement), the average concentration set in summer yielded notably larger resolved MMDs in both modes and greater Aitken-mode mass compared to the median, 25th, and 75 th percentile concentration sets. This indicates a strong influence of extreme values (i.e., time periods with both larger particle size and larger particle mass concentrations) and thus greater variability in size distributions in the warmer season caused by specific high- and low-concentration events such as photochemical episodes and precipitation, evident in the greater relative span of organic mass concentrations in summer (See Table S5 in the Supplement: ratio of 10th and 90th percentiles to median concentration in NR-PM 1 ). In spring, such events masked the diurnal processes to a lesser extent and with consequently greater consistency across different size distribution sets.

\section{Sulfate}

Although variations in total submicron sulfate mass concentrations with time of day were generally subtle, distinct trends were notable in MMDs and integrated-mode mass concentrations in both the Aitken and accumulation modes.

Generally, Aitken-mode MMDs were $20 \%$ larger in spring $(180 \mathrm{~nm})$ than in summer $(150 \mathrm{~nm})$. While in spring fluctuations in Aitken-mode MMDs were small throughout the day within a narrow range of $\pm 10 \mathrm{~nm}$ and without apparent regular features, the summertime diurnal variation exhibited a well-defined broad daytime peak with a shift to $\sim 15 \mathrm{~nm}$ larger particle diameters. A matching trend was evident in the accumulation mode where MMDs increased by $\sim 20 \mathrm{~nm}$ in summer. Conversely, in spring, a conspicuous nighttime peak in accumulation-mode MMDs was observed in the low traffic period between 01:00 and 07:00, which tracked closely with the diurnal variation in $\mathrm{O}_{3}$, which peaked in the same period due to the reduction of the $\mathrm{NO}_{x}$ titration effects at low nighttime traffic volumes. While particulate sulfate production during the day can be achieved through both homogeneous gas-phase oxidation of $\mathrm{SO}_{2}$ by the $\mathrm{OH}$ radical as well as heterogeneous oxidation of $\mathrm{SO}_{2}$ by dissolved $\mathrm{H}_{2} \mathrm{O}_{2}$ or $\mathrm{O}_{3}$
(Seinfeld and Pandis, 2006), nighttime production is limited to the non-photochemical heterogeneous pathway. The apparent increase in accumulation-mode particle size was also associated with an increase in integrated submode particle mass of $\sim 0.7 \mu \mathrm{g} \mathrm{m}^{-3}$ and thus suggests the possibility of heterogeneous $\mathrm{SO}_{2}$ oxidation by residual ozone in the cooler and more humid spring season as a local source of particulate sulfate. In the warmer and drier summer season, no corresponding trend was apparent in either accumulationmode MMD or integrated-mode concentration. The small magnitude of additionally produced sulfate $\left(<1 \mu \mathrm{g} \mathrm{m}^{-3}\right)$ in spring renders the nighttime production a minor source of particulate sulfate, however, and affirms that the bulk of the accumulation-mode sulfate burden at the urban roadside still originated from regional-scale processes in both seasons. In summer, both modes exhibited notable increases in particle mass concentration levels during the daylight hours of $\sim 80 \%$ in the Aitken mode and of $\sim 35 \%$ in the accumulation mode compared to their respective nighttime baseline concentrations. Integrated over the whole day, the additional sulfate burden above this baseline amounted to $0.4 \mu \mathrm{g} \mathrm{m}^{-3}$ and $6 \mu \mathrm{g} \mathrm{m}^{-3}$ and thereby accounted for 34 and $11 \%$ of the total daily Aitken- and accumulation-mode particle mass, respectively. This represents a rough estimation of possible local photochemical contributions to the Aitken and accumulation size mode in summer at the urban roadside, excluding possible physical effects, e.g., vertical mixing and advection or dilution laterally through the street canyon. Enhancements in particle mass by photochemical contributions were more pronounced in the Aitken mode, with the median fraction of Aitken-mode particle mass among total AMS-measured particle mass increasing substantially from its nighttime minimum at $4 \%$ to a maximum of $7 \%$ in the late afternoon in summer, while in spring the fraction remained almost constant at $6 \%$ throughout the day (Fig. 3a).

Considering different size distribution sets (Fig. S6 in the Supplement), the 75th percentile size distributions and the average size distributions displayed notable increases in Aitken-mode particle mass during the nighttime of $20-50 \%$ in spring. There was no corresponding trend in the accumulation mode, in which changes in integrated mass concentration remained consistently $<10 \%$. The skewing of the average and higher percentile data indicates the influence of time periods with significantly elevated nighttime concentrations, likely related to events and atmospheric conditions conducive to the extensive formation of Aitken-mode sulfate particles. The accumulation mode showed no notable changes in the average and 75th percentile data during the same time period, thus precluding physical processes such as transport or lowering of the planetary boundary layer as likely influential factors for these observations. 


\section{Nitrate}

Particulate nitrate mass concentrations in the Aitken and accumulation modes exhibited similar diurnal variations in spring with lower daytime concentrations due to evaporation and higher nighttime concentrations in which secondary formation and gas-to-particle partitioning prevailed. Analogous to sulfate, the Aitken-mode MMDs for nitrate showed little change $(<5 \%)$ throughout the day in both seasons. Aitkenmode mass concentrations, however, exhibited a twofold increase over the dinner hours, accounting for approximately $0.9 \mathrm{\mu g} \mathrm{m}^{-3}(\sim 16 \%)$ of additional particle nitrate mass per day. This may be due to the much higher abundance of small particles from cooking emissions providing additional surface area to facilitate gas-to-particle partitioning of nitrate. Increased signal intensities of oxygenated organic nitrogen ions (see Fig. S11 in the Supplement) have also been observed during dinner, suggesting that organic nitrate or other oxygenated nitrogen-containing organic species that produce nitrate fragments (Farmer et al., 2010) may too have contributed to this observed concentration peak. Accumulationmode nitrate mass increased by almost one-third in the low traffic period (01:00-07:00) compared to earlier night concentration levels (22:00-00:00) accompanied by a slight increase in MMD of $\sim 10 \mathrm{~nm}$ in spring. This signifies notable nighttime nitrate production through possibly nitric acid formation by ozone chemistry via the nitrate radical route under influence of organic components or formation of $\mathrm{N}_{2} \mathrm{O}_{5}$ and subsequent hydrolysis during the night. Local nighttime nitrate production effectively contributed $\sim 3 \mu \mathrm{g} \mathrm{m}^{-3}(\sim 10 \%)$ to the total daily accumulation-mode nitrate burden in spring.

Summertime nitrate production in Hong Kong has been mainly attributed to photochemical activity based on previous measurements of inorganic gas- and particle-phase nitrogen species at the suburban HKUST site (Griffith et al., 2015). Particulate nitrate mass concentrations at the urban Mong Kok site likewise exhibited clear daytime peaks, similar to sulfate albeit at a smaller magnitude with total integrated increases of $\sim 0.3$ and $\sim 0.8 \mu \mathrm{g} \mathrm{m}^{-3}$ of particulate nitrate per day in the Aitken and accumulation modes, respectively. In the Aitken mode, particle mass remained elevated in the early night hours $(\sim$ 19:00-22:00), which was likely due to the previously mentioned cooking-related nitrate enhancement analogous to spring. The distribution of total submicron nitrate shifted slightly in favor of the Aitken mode in summer, with $\sim 18 \%$ of total submicron nitrate found in the Aitken mode compared to $\sim 14 \%$ in spring.

Comparing different size distribution sets (Fig. S6 in the Supplement), the average size distributions displayed notable disparity compared to the remaining sets in both seasons. In summer, integrated particle mass concentrations and MMDs from the average set exhibited consistently larger values than those from the 25 th percentile, 75 th percentile, and median sets indicating significant influence of time periods with high nitrate concentrations and larger nitrate-containing particles.
In spring, the average data exhibited a decrease in MMD in the Aitken mode from night to day, implying prolonged periods of significantly smaller daytime Aitken-mode particles.

\subsubsection{Suburban coastal NR-PM}

The suburban HKUST site as a downwind receptor of urban and regional pollution was generally dominated by sulfate and oxygenated SOA components and much lower fractions of primary organic constituents, which combined typically made up less than a quarter of total organics ( $\mathrm{Li}$ et al., 2015). Trends in the species-segregated particle size distributions are discussed analogously to Sect. 3.1.1, with Fig. 4 illustrating the diurnal trends in the fitting parameters (MMD, integrated-mode mass, geometric standard deviation) for organics, sulfate, and nitrate at the suburban HKUST site.

\section{Organics}

There were significant seasonal differences with larger fractions (Fig. 3b) and concentrations (Fig. 5c) of Aitken-mode mass in total organic submicron particle mass in spring and summer compared to fall and winter, indicating greater influence of closer-range formation sources in the warmer season. Springtime integrated Aitken-mode mass concentrations $\left(\sim 0.8 \mu \mathrm{g} \mathrm{m}^{-3}\right)$ were twice as high as those in winter $\left(\sim 0.4 \mu \mathrm{g} \mathrm{m}^{-3}\right)$. In the accumulation mode, the highest particle mass loadings were observed in fall $\left(5 \mu \mathrm{g} \mathrm{m}^{-3}\right)$ and the lowest loadings in spring $\left(3 \mu \mathrm{g} \mathrm{m}^{-3}\right)$ following the frequency pattern of continental air mass influence (Fig. S12 in the Supplement) in each season indicating continental transport of particulate mass or gas-phase precursors. The lowest mass concentrations in the Aitken mode typically occurred in the night hours (00:00-05:00) in a range of 0.3$0.5 \mu \mathrm{g} \mathrm{m}^{-3}$ in spring, summer, and winter, while in fall mass loadings of $0.7-0.8 \mu \mathrm{g} \mathrm{m}^{-3}$ were reached. Diurnal changes were least pronounced in winter, with largely constant integrated Aitken-mode particle concentrations. In the remaining seasons, varying degrees of daytime changes were apparent, with a general increase around 06:00, likely owing to city-bound commuter traffic from surrounding roads to the west of the sampling site at $1-2 \mathrm{~km}$ lateral distance. This also led to a modest increase in particle polydispersity with a discernible widening of the Aitken-mode size distributions (Fig. 4a-c). Daily maxima in spring, summer, and fall were reached in the early evening $(\sim 21: 00)$ with marked differences in absolute mass concentrations depending on the respective season, from a summertime low of $0.8 \mu \mathrm{g} \mathrm{m}^{-3}$ to a fall season high of $1.4 \mu \mathrm{g} \mathrm{m}^{-3}$. MMDs in the Aitken mode were smaller in the night hours and displayed subtle increments during the day in the range of $10-20 \mathrm{~nm}$, reaching their maximum typically in the late afternoon, except for the fall season when MMDs displayed very little variation with time of day. 

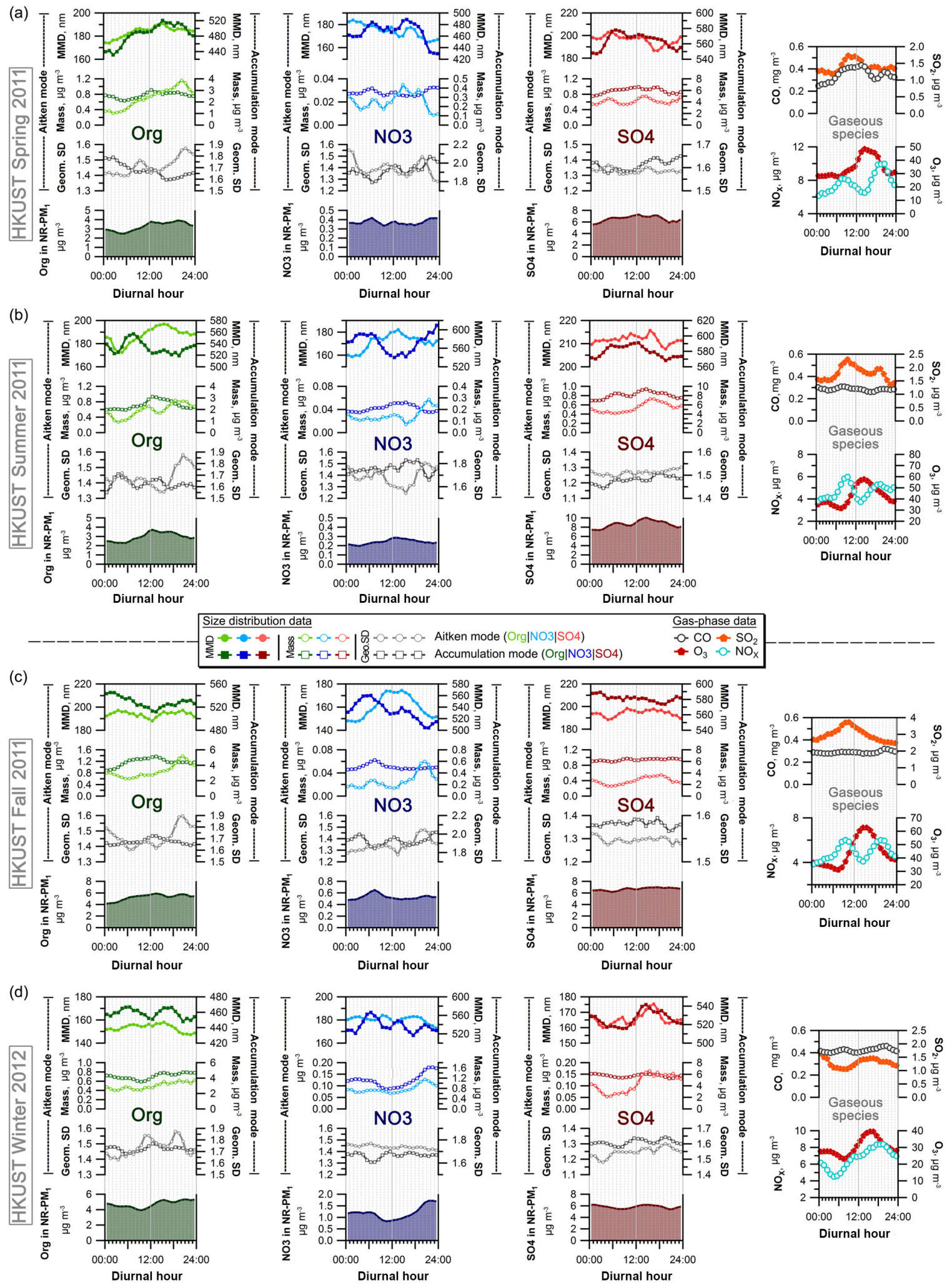

Figure 4. Diurnal variations in mode diameter (MMD), integrated-mode mass concentration, and width of the Aitken mode (lighter color) and accumulation mode (darker color) from bimodal peak fits of the bin-median reconstructed size distributions at the suburban HKUST site, as well as V-mode AMS species concentrations (line with shaded background) for organics, nitrate, and sulfate (left to right) in (a) spring 2011, (b) summer 2011, (c) fall 2011, and (d) winter 2012. The right-most panels depict the median diurnal variations in relevant gas-phase pollutants $\left(\mathrm{O}_{3}, \mathrm{CO}, \mathrm{NO}_{x}, \mathrm{SO}_{2}\right)$ measured at the same site. 

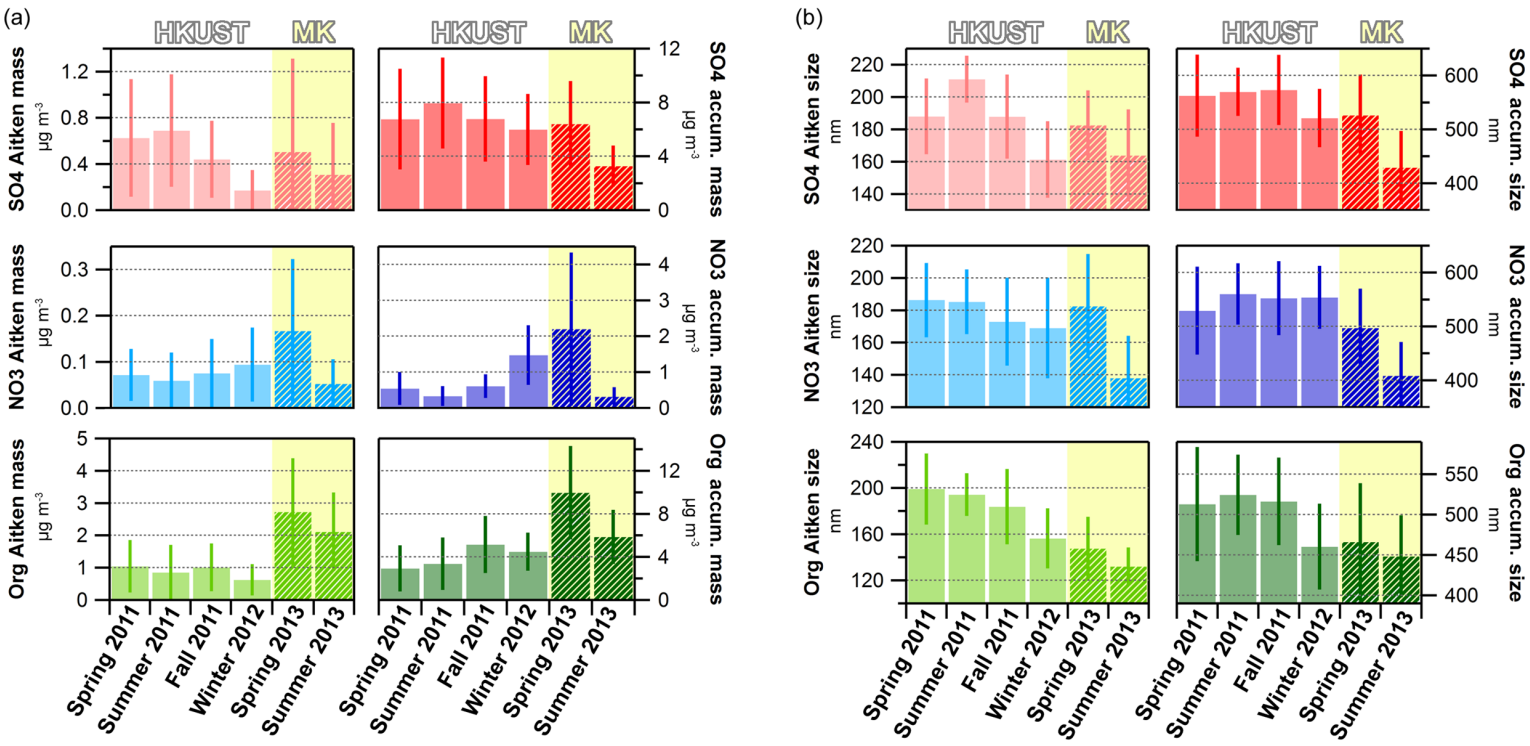

Figure 5. Average and standard deviation of daily fit values of Aitken- and accumulation-mode particle mass and mass median diameters at the suburban HKUST site (solid bars) and urban MK site (hashed bars). The integrated particle mass is depicted in (a) for the Aitken mode (left panels) as well as the accumulation mode (right panels) for sulfate, nitrate, and organics. The mass median diameter is depicted in (b) for the Aitken mode (left panels) as well as the accumulation mode (right panels) for sulfate, nitrate, and organics.

Total particle mass in the accumulation mode in spring and summer reached minima during the night hours $\left(2 \mu \mathrm{g} \mathrm{m}^{-3}\right)$ and maxima $\left(3 \mu \mathrm{g} \mathrm{m}^{-3}\right)$ around noon, remaining stable in the daylight hours thereafter. MMDs increased notably from $440 \mathrm{~nm}$ at night to $510 \mathrm{~nm}$ during the day in spring, while in summer a morning rise of $\sim 30 \mathrm{~nm}$ from 530 to $560 \mathrm{~nm}$ was obvious between 06:00 and 10:00 and coincided with the morning rush hour and the associated early morning peak of $\mathrm{NO}_{x}$ and an otherwise stable mode diameter of $530 \mathrm{~nm}$ for the rest of the day. In fall, the increase in accumulation mode organic mass occurred much earlier, starting in the dark hours at 04:00, with a corresponding trend also evident for nitrate but absent for sulfate, indicating a common source of these organic- and nitrate-enriched particles. Nighttime MMDs for organics were generally larger $(540 \mathrm{~nm})$ and decreased to a minimum of $510 \mathrm{~nm}$ in the early afternoon accompanied by a slight widening of the distribution. In winter, mass concentrations decreased appreciably in the early morning hours and started to increase only after 10:00. In the colder seasons (fall, winter), a similar concentration pattern was also observed for gas-phase $\mathrm{SO}_{2}$, which is considered as a largely regional pollutant with few distinct local sources (Yuan et al., 2013), indicating that changes in boundary layer and mixing with regional background were likely the more dominant processes in winter.

\section{Sulfate}

Aitken-mode sulfate mass concentrations peaked in the afternoon from spring throughout fall with maximum concentrations reached progressively later in the afternoon (14:00 in spring; 16:00 in fall). Nominal concentrations were highest in spring and summer $\left(0.5-0.6 \mu \mathrm{g} \mathrm{m}^{-3}\right)$, slightly lower in fall $\left(0.4 \mu \mathrm{g} \mathrm{m}^{-3}\right)$ and reached the lowest levels in winter $\left(0.1 \mu \mathrm{g} \mathrm{m}^{-3}\right)$. In addition to the afternoon peak, a conspicuous early morning peak of similar magnitude was evident in spring between 02:00 and 06:00. A greater proportion of southerly winds was evident in said time period compared to the overall seasonal wind frequency distribution (Fig. S13a in the Supplement) and may indicate transport of sulfate from marine sources in the southern parts of Hong Kong. Diurnal variations in MMDs and GSDs were generally small and without obvious regular trends. Nominal MMDs were significantly lower in winter $(\sim 170 \mathrm{~nm})$ compared to spring and fall $(\sim 190 \mathrm{~nm})$ and summer $(\sim 210 \mathrm{~nm})$.

Trends in accumulation-mode particle mass were more pronounced. In spring, a shallow concentration valley during the late evening and night hours (20:00 to 03:00) with minimum concentrations of $5 \mu \mathrm{g} \mathrm{m}^{-3}$ was apparent, while daytime concentrations stayed largely invariant at $6 \mu \mathrm{g} \mathrm{m}^{-3}$. The MMDs followed a similar variation, with a minimum mode diameter around $550 \mathrm{~nm}$ in the early hours of the day and slightly larger daytime MMDs around $570 \mathrm{~nm}$. Nominal concentrations were larger in summer, with a nighttime valley concentration of $7 \mu \mathrm{g} \mathrm{m}^{-3}$ and a well-pronounced broad day peak with a maximum of $9.5 \mu \mathrm{g} \mathrm{m}^{-3}$ in the early afternoon (14:00-15:00). A prior additional morning peak occurred between 04:00 and 10:00, with particle mass concentrations reaching $8.5 \mu \mathrm{g} \mathrm{m}^{-3}$ related to a consistent northeasterly morning wind pattern (Fig. S13b in the Supplement) and likely associated with transport from northeasterly coastal re- 
gions or nighttime fishing-related maritime traffic. The diurnal trend in MMD was similar to that in spring with a night minimum of $570 \mathrm{~nm}$ and day maximum of $590 \mathrm{~nm}$.

In fall, accumulation-mode characteristics showed no significant diurnal variability, with a largely stable integrated particle mass of $6 \mu \mathrm{g} \mathrm{m}^{-3}$ and only subtle MMD changes (585 nm at night; $575 \mathrm{~nm}$ during the day). In winter, two concentration dips with reductions of $\sim 0.5 \mu \mathrm{g} \mathrm{m}^{-3}$ between 06:00 and 10:00 and between 18:00 and 22:00 were evident, while MMDs increased during the day between 10:00 and 15:00 from $520 \mathrm{~nm}$, peaking at a size of $540 \mathrm{~nm}$.

\section{Nitrate}

Nitrate particle mass in the Aitken mode was generally small from spring throughout fall, amounting to $0.01-0.06 \mu \mathrm{g} \mathrm{m}^{-3}$. Wintertime concentrations were larger in a range of $0.06-$ $0.08 \mu \mathrm{g} \mathrm{m}^{-3}$ during the day and $0.10-0.12 \mu \mathrm{g} \mathrm{m}^{-3}$ in the late evening hours. The latter evening peak centered around 21:00 was evident in most seasons (except spring) and accounted for $12-23 \%\left(0.1-0.25 \mu \mathrm{g} \mathrm{m}^{-3}\right)$ of total daily Aitken-mode nitrate mass burden. Similar to the urban roadside location, these nighttime nitrate peaks coincided with the peak period of COA concentrations (Fig. S14 in the Supplement), which were however significantly smaller at the suburban measurement site and mainly attributed to the operation of an oncampus student canteen ( $\mathrm{Li}$ et al., 2015). Trends in mass median diameters varied between seasons, with no discernible trend in winter, a subtle decreasing trend with time of day in spring, and broad diameter increases in the daytime in summer and fall. Solar irradiation in these two seasons was comparatively high (Fig. S10b-c in the Supplement), indicating that photochemical nitrate production in the Aitken mode may have led to this observed growth in particle size.

Integrated particle mass concentrations in the accumulation mode only exhibited subtle variations from spring throughout fall, with essentially constant diurnal concentrations in spring, a subtle daytime peak in summer, which accounted for $\sim 15 \%$ of total daily accumulation-mode nitrate (corresponding to $0.7 \mu \mathrm{g} \mathrm{m}^{-3}$ ), and a conspicuous morning peak between 04:00 and 10:00 in fall accounting for $\sim 5 \%$ of total daily accumulation-mode nitrate (corresponding to $0.5 \mu \mathrm{g} \mathrm{m}^{-3}$ ). Clearer seasonal differences were evident in the trends of MMDs. In spring, MMDs decreased appreciably over the late evening hours (21:00-0:00) with a concurrent widening of the size distribution (increase in GSD). In summer, accumulation-mode diameters decreased during the day by $\sim 40 \mathrm{~nm}$ with a similar trend in accumulation-mode organics. Wintertime MMDs exhibited a more complex pattern with larger mode diameters in the early hours (04:00-10:00) and during the noontime and a late-afternoon dip leading to larger spread of intra-day mode diameters ranging from 510 to $570 \mathrm{~nm}$.

In comparison to the urban roadside measurements, diurnal particle size characteristics and mass concentrations in the Aitken and accumulation modes were much more variable for all investigated species at the suburban HKUST site, indicating that longer timescale processes and irregular events (transport patterns, local meteorology) were probably more important in governing particle size distribution characteristics than diurnal processes.

\subsection{Day-to-day size distributions and seasonal averages}

To evaluate the evolution of particle size distributions within seasons, average species-specific size distributions were generated by averaging raw distributions over $24 \mathrm{~h}$ periods (between 00:00 and 23:59). There was clear long-term variability in both resolved Aitken- and accumulation-mode MMDs and integrated submode particle mass concentrations for all species (Figs. S15-S16 in the Supplement). There were also overall seasonal differences, which have been briefly addressed in the discussion of the diurnal size distribution variations between seasons. Figure 5 depicts the overall average values for all daily fitted MMDs and integrated particle mass concentrations in both the Aitken and accumulation modes at the suburban HKUST and urban MK sites.

\subsubsection{Seasonal trends}

For the MK roadside station, particle mode diameters were generally larger in spring than in summer for all three investigated species, but with clear differences in the magnitude of changes among individual species. In the Aitken mode, organics and sulfate displayed a moderate decrease in mode diameter from spring to summer of 7-8\% each, while nitrate saw a more significant decrease of $25 \%$ from spring to summer. In contrast, accumulation-mode MMDs for organics exhibited only a subtle decrease of $5 \%$ and more substantial decreases for sulfate and nitrate of $20-22 \%$ each. Total Aitken-mode particle mass decreases varied strongly: $-15 \%$ for organics, $-36 \%$ for sulfate, and $-67 \%$ for nitrate. In the accumulation mode, organics and sulfate exhibited similar relative decreases of $40-46 \%$, while nitrate particle mass reduced drastically by $85 \%$.

At the suburban HKUST site, Aitken-mode MMDs of nitrate and organics decreased with the progression of seasons from spring to winter with the highest mode diameters observed in spring and summer and appreciable decreases in winter of $-9 \%$ for nitrate and $-25 \%$ for organics compared to the warmer seasons. Sulfate displayed a similar wintertime decrease in MMD $(-15 \%)$ and an increase of similar magnitude in the summer season $(+13 \%)$ compared to spring and fall. Variations in sulfate and organic accumulation-mode diameters were minor between spring and fall, while wintertime MMDs were 7-12\% lower. Nitrate exhibited an overall higher variability in mass median diameters in the accumulation mode in spring (larger standard deviation) and with MMDs an average of $10 \%$ lower compared to other seasons. In line with the reduction in Aitken-mode MMDs in 
winter, the integrated Aitken-mode particle mass decreased as well, by $-16 \%$ for organics and almost $-75 \%$ for sulfate, whereas nitrate contributions remained largely stable throughout the seasons. Organic accumulation-mode particle mass was significantly higher in the fall and winter seasons by factors of 1.6-2. Diurnal variations in the degree of oxygenation were least pronounced in these seasons ( $\mathrm{Li}$ et al., 2015), suggesting that influence of transport in autumn and winter likely dominated over local formation, thus exerting greater effects on particle mass in the larger size mode. Particulate nitrate concentrations were generally low in the accumulation mode from spring through fall, but increased sharply in winter by factors of 3-4. Sulfate accumulationmode mass concentrations remained more stable but saw significant summertime enhancements of $\sim 30 \%$ likely due to photochemical activity, which also led to high concentrations of $\mathrm{O}_{x}$ and a higher degree of oxygenation of organic aerosol among the four seasons (Li et al., 2015).

Large particles contribute more to particle volume and hence particle mass. Correspondingly, the total submicron concentration of a given species is typically governed by changes in the accumulation-mode particle mass. Accordingly, observed correlation values between integrated accumulation-mode particle mass and individual NR-PM ${ }_{1}$ species mass concentrations were generally high $\left(R_{\mathrm{pr}}>0.90\right)$ at both measurement sites (Fig. S17 in the Supplement). This applied to both measurement sites regardless of the season. Aitken-mode trends were less similar. At the urban roadside station, neither sulfate nor nitrate particle mass in the Aitken mode notably correlated with the respective total submicron species mass concentration in spring (all $R_{\mathrm{pr}} \leq 0.20$ ), whereas in summer correlations were more significant, with $R_{\mathrm{pr}}=0.51$ for sulfate and $R_{\mathrm{pr}}=0.80$ for nitrate. This signifies that periods of greater species mass concentrations were more likely to be caused by increases in both Aitken- and accumulation-mode particle mass, indicating that particle formation and growth affecting smaller particles was more likely to occur in the warmer season. For organics, Aitken-mode particle mass and submicron species mass correlated only weakly $\left(R_{\mathrm{pr}}=0.26\right.$ in spring and $R_{\mathrm{pr}}=$ 0.38 in summer), i.e., each organic particle submode was governed by largely different dominant sources or formation processes in both seasons at the roadside.

At the suburban background site, Aitken-mode particle mass for sulfate showed little correlation with total submicron sulfate concentration $\left(R_{\mathrm{pr}} \leq 0.10\right)$ apart from the spring season $\left(R_{\mathrm{pr}}=0.36\right)$ in which more frequent wet and foggy conditions may have facilitated sulfate formation in both size modes. For organics and nitrate, significantly larger correlation coefficients of submode particle mass to total species concentration $\left(0.5 \leq R_{\mathrm{pr}} \leq 0.7\right)$ were observed in most seasons (spring, summer, winter), indicating significant influence of local or regional formation processes on organic and nitrate Aitken-mode particulate mass at the suburban receptor location. In the fall season, much weaker correlations $\left(0.2 \leq R_{\mathrm{pr}} \leq 0.4\right)$ were likely caused by the dominance of continental air mass influence (Fig. S12c in the Supplement) and greater influence of aged accumulation-mode particles on total submicron nitrate mass concentrations.

\subsubsection{Inferred changes in mixing state}

Shifts in mixing state of ambient particles can be inferred from the interspecies analysis of MMDs. Close nominal agreement (i.e., diameter ratios close to 1 ) infers that different species were distributed similarly across the particle size range, which thus most likely represents a largely internally mixed particle population, while the spread of data (correlation coefficient) indicates the temporal homogeneity or divergence of resolved mode diameters. A hypothetically perfectly internally mixed particle population over the whole sampling period would, therefore, yield MMD ratios and Pearson's $R$ values of 1 between species, while larger or smaller values are indicative of a greater frequency of heterogeneous (i.e., more externally mixed) particle populations (Fig. 6).

At the urban Mong Kok site, changes in accumulationmode MMDs for nitrate and sulfate followed similar trends $\left(R_{\mathrm{pr}}=0.88-0.89\right)$ and with diameter ratios close to $1(0.94-$ $0.95)$. Similarly, fitted accumulation-mode diameters of organic constituents predominantly followed those of sulfate in spring nominally (diameter ratio 0.88 ) and temporally $\left(R_{\mathrm{pr}}=0.80\right)$. The nominal agreement of organic and sulfate accumulation-mode diameters persisted (diameter ratio 1.03) overall in summer; however, there was significantly more temporal divergence $\left(R_{\mathrm{pr}}=0.65\right)$, indicating a greater frequency of time periods, with external mixing of particle populations comprising different fractions of organic constituents.

External mixing is more prevalent for freshly formed smaller particles, which have typically undergone less condensational growth, coagulation, or aqueous-phase reactions. Indeed, the correlation coefficients of both nitrate and organic Aitken-mode MMDs with respect to sulfate were notably lower ( 0.50 and 0.62 ), indicating frequent periods of particle populations with different species prevailing in different size regions within the Aitken mode.

Sulfate and nitrate were still more likely to occur internally mixed in the Aitken mode in spring with similar diameters (nitrate to sulfate MMD ratio = 1.00), while organic Aitken-mode MMDs were consistently lower, indicating greater fractions of organic-dominated particles towards the lower end and more inorganic-dominated particles towards the upper end of the fitted Aitken mode.

In summer, both nitrate and organic MMDs tended to be lower than those of sulfate (diameter ratios of $0.79-0.83$ ) but similar to each other, thus implying a shift to externally mixed populations of more smaller nitrate- and organicenhanced and internally mixed Aitken-mode particles and larger sulfate-dominated Aitken-mode particles. 
(a)

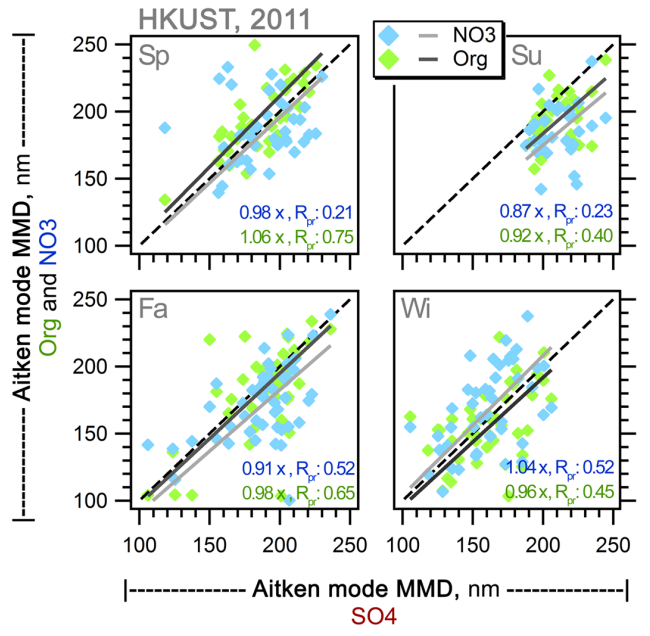

(c)

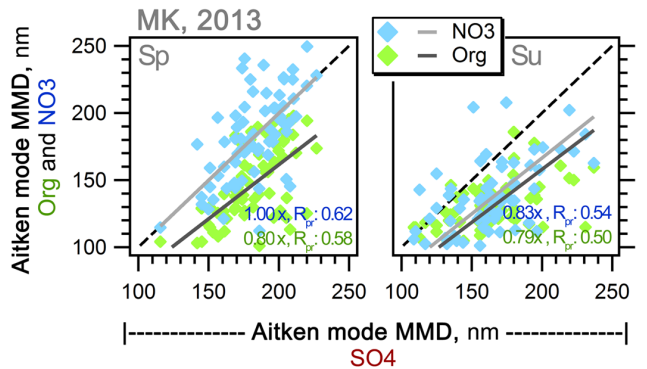

(b)

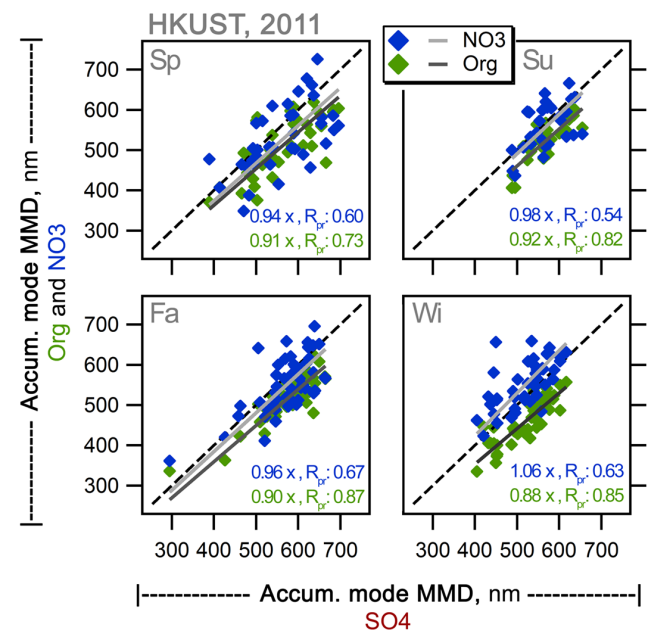

(d)

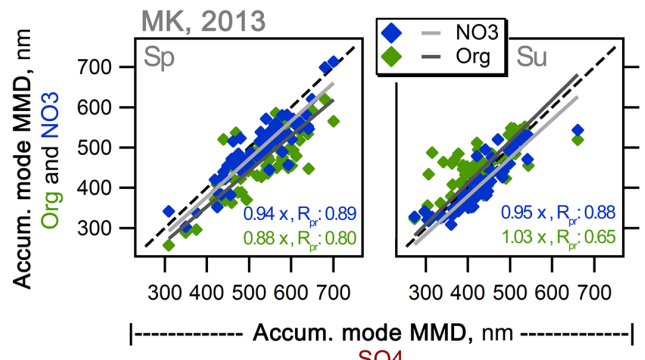

$\mathrm{SO} 4$

Figure 6. Scatter plots of fitted mass median diameters of organics and nitrate vs. sulfate for (a) the Aitken mode and (b) the accumulation mode at the HKUST suburban site and (c) the Aitken mode and (d) the accumulation mode at the urban Mong Kok site.

At the suburban HKUST site, accumulation-mode MMDs of both nitrate and organics were generally quite similar to those of sulfate, with diameter ratios of 0.88-1.06. Compared to the urban site, correlation coefficients of nitrate and sulfate were consistently lower (0.54-0.67), indicating a much greater frequency of time periods in which sulfateand nitrate-dominated particles in the accumulation exhibited significantly different particle size distributions.

In winter, organic MMDs were consistently lower than those of sulfate and nitrate, indicating a greater proportion of externally mixed particle populations with organics-enriched particles in the lower accumulation size range and inorganicdominated particles in the larger accumulation size range. The least variability in particle size was observed in the summer season when MMDs in both Aitken and accumulation mode displayed variations in relatively narrow ranges between $200-250$ and $500-700 \mathrm{~nm}$, whereas in the remaining seasons, time periods with particle populations of lower MMD were more frequent, extending to MMDs as low as $100 \mathrm{~nm}$ in the Aitken mode and $300 \mathrm{~nm}$ in the accumulation mode.

In the Aitken mode, mass median diameters overall were quite similar across species, with diameter ratios of organic and nitrate distributions to those of sulfate in the range of
$0.87-1.06$, indicating that they generally covered a similar size range. The temporal agreement was highly variable, with correlation coefficients $\left(R_{\mathrm{pr}}\right)$ spanning from 0.21 to 0.75 , indicating that Aitken-mode particle populations at the suburban site were generally more diverse and likely influenced by a greater range of particle formation and growth mechanisms compared to the urban Mong Kok site.

\subsection{Comparison to previous studies}

Particle size distribution studies in Hong Kong are generally scarce and have focused on either size segregated filter samples (MOUDI) for general ambient measurements or electrostatic classification in particle formation and particle growth studies (Guo et al., 2012; Cheung et al., 2015). The latter studies focus on specific and narrow time periods and lack general discussions on ambient particle size distributions.

Two ambient studies were undertaken at the suburban coastal HKUST site using size-segregated samples from a 10-stage MOUDI sampler and offline chromatographic analysis. Inorganic constituents $\left(\mathrm{NH}_{4}, \mathrm{NO}_{3}, \mathrm{SO}_{4}\right)$ in fine particles (i.e., $D_{\mathrm{p}}<1.8 \mu \mathrm{m}$ ) were shown to follow bimodal distributions with mode diameters in the range of 0.14-0.21 and $0.46-0.58 \mu \mathrm{m}$ in samples collected in the winter season, while the main mode was observed in the coarse region (4- 
$6 \mu \mathrm{m})$ for all three species (Zhuang et al., 1999). A subsequent year-long observational study also reported bimodal fine particle distributions with mode diameters of $0.1-0.3 \mu \mathrm{m}$ and $0.7-0.9 \mu \mathrm{m}$ and one to two additional modes in the coarse region (Bian et al., 2014); however, the main mode in the size distributions of sulfate, ammonium, potassium, and oxalate was observed in the droplet mode $(0.7-0.9 \mu \mathrm{m})$ in this study. Vehicle exhaust plumes sampled on-road from a Mobile Real-time Air Monitoring Platform (MAP) across Hong Kong's road network exhibited three distinct particle volume size distributions: a unimodal distribution with an accumulation mode at $0.2 \mu \mathrm{m}$ and two bimodal distributions with a minor mode at $0.2 \mu \mathrm{m}$ and the dominant mode at 0.5 or $0.7 \mu \mathrm{m}$ (Yao et al., 2007b).

The bimodality in the fine particle range across these studies is consistent with the AMS-based results in this work. Nominally, the accumulation-mode diameters from filterbased studies and the chase studies are larger than those from AMS measurements in which maximum mode diameters occurred at $D_{\mathrm{va}} \sim 700 \mathrm{~nm}$, corresponding to $D_{\mathrm{a}} \sim 470$ (assuming $D_{\mathrm{va}} \sim D_{\mathrm{a}} \cdot$ density; particle density $\sim 1.5 \mathrm{~g} \mathrm{~cm}^{-3}$ ). Direct comparability is however limited due to fundamental differences in sizing techniques (MOUDI: atmospheric pressure; AMS: near-vacuum), sampling times (MOUDI: $24 \mathrm{~h}$ samples, scattered time line; AMS: minute raw resolution averaged to hourly or daily, continuous time line), measurement uncertainties (MOUDI: sampling artifacts such as vapor adsorption and desorption; AMS: inlet lens transmission), and aerosol pretreatment (none for MOUDI with potential impacts on particle size in high humidity ( $>80 \%$ ) conditions (Fang et al., 1991); AMS: removal of water prior to introduction to instrument).

\subsection{Influence of AMS lens transmission}

The quantitative measurement of particle components in the AMS is dependent on three major factors that may lead to particle loss prior to detection (Huffman et al., 2005). Irregularly shaped particles deviating from the flight path in the vacuum chamber may miss the vaporizer. Particles bouncing off the vaporizer surface will not be vaporized and hence may not be detected. Lastly, the aerodynamic lens that is part of the instrument's inlet system does not transmit particles uniformly across all particle diameters. Small particles are lost due to insufficient focusing or diffusion and large particles impact the lens apertures (Liu et al., 2007; Williams et al., 2013). Being a function of particle size, the latter factor affects both total AMS quantifiable particle mass (NR-PM ${ }_{1}$ ) and measured mass size distributions. Transmission curves determined for the standard lens, which is fitted in most AMS instruments, can vary but typically show efficient (i.e., close to $100 \%$ ) transmission in the range of $100-550 \mathrm{~nm}$ (Knote et al., 2011) falling off significantly at either edge.

We examined the potential impact of lens transmission on the AMS mass size distributions on a number of $24 \mathrm{~h}$ size distributions from the fall season HKUST dataset covering both efficient and reduced lens transmission size regimes (accumulation-mode diameters between 400 and $600 \mathrm{~nm}$ ). Panels $(\mathrm{a}-\mathrm{c})$ in Fig. S18 in the Supplement depict original and lens-transmission-corrected $24 \mathrm{~h}$ mass size distributions for organics, nitrate, and sulfate, assuming the transmission function (subpanel d) reported by Liu et al. (2007). Impacts were generally larger in the accumulation-mode range, with evident shifts to larger mode diameters and larger mode mass concentrations observed in all size distributions. In the small diameter range, enhanced shoulders can occur, which may however be artifacts due to the larger uncertainties (low signal-to-noise ratio at small particle mass), i.e., greater noisiness at the leading end of AMS size distributions. For a quantitative comparison, bimodal fitting parameters from the corrected distributions were plotted against those from the original distributions in Fig. S18 in the Supplement (subpanels $e-g$ refer to the Aitken mode and subpanels $h-j$ to the accumulation mode). Leading edge shoulders in the corrected size distributions were not considered in the fitting. Changes in the Aitken-mode MMDs were minor (on average $\sim 3 \%$ ), while the integrated-mode particle mass increased moderately $(\sim 48 \%)$. In the accumulation mode, MMDs increased by $\sim 28 \%$ and integrated-mode particle mass doubled. The distribution widths (GSDs) exhibited little change in both modes (increases of 2-3\%).

Fitting results will therefore vary depending on whether AMS size distribution and concentration data are corrected for lens transmission. While explicit lens transmission corrections can improve the accuracy of quantification of AMS species concentration and size distribution measurements, few ambient studies explicitly use lens transmission corrections based on individual experimental determinations or literature values (e.g., Quinn et al., 2006; Cross et al., 2007). Lens transmission curves can vary between instruments (Fast et al., 2009) and are inherently difficult to determine accurately experimentally. As discussed previously, scaling of size distributions using lens transmission curves may introduce artifacts in noisier size distributions (e.g., low end of the Aitken mode, low concentration periods, short-term size distribution averages). Trailing edges from slow vaporization (e.g., under high particle mass loadings) may be exacerbated and inflate mass concentrations at the upper size cut range of the AMS. The majority of ambient studies employ a combined correction factor (collection efficiency, CE) considered to be the joint product of the previously mentioned transmission efficiencies related to particle bounce, beam broadening, and lens transmission (Middlebrook et al., 2012) derived from aerosol composition and by comparison to collocated speciation or particle sizing instruments. As the AMS lens transmission curve could not be determined in this study and to avoid additional uncertainties from the application of noninstrument-specific lens transmission values, we followed the CE correction method in the analysis of the size distribution data in this study. The reported values of resolved mode di- 
ameters and integrated mode should therefore be regarded as lower-bound estimates in the context of the instrumental limitations affecting ambient AMS measurements.

\section{Conclusion}

A detailed analysis of AMS mass-based particle size distributions of sulfate, nitrate, and organics in submicron particulate matter measured at two contrasting locations in Hong Kong during two field campaigns has been undertaken. Deconvolution of size distributions into Aitken and accumulation submodes was accomplished using log-normal peak fitting, and trends in particle size (mass median diameters), dispersity (geometric standard deviation), and overall particle mass (integrated mode area) were discussed on a diurnal timescale and on a daily basis to evaluate longer-term changes in size distribution characteristics. At the urban roadside location, clear diurnal influences of primary particle and gas-phase species were evident, affecting both inorganic and organic component size distributions. Traffic and cooking contributed an estimated $0.3-0.9$ and $0.5-1.8 \mu \mathrm{g} \mathrm{m}^{-3}$, respectively, of organic component particle mass in the Aitken mode and $1.6-1.8$ and $1.0-2.7 \mu \mathrm{g} \mathrm{m}^{-3}$, respectively, in the accumulation mode, with concentration levels varying with seasons. Notable changes in Aitken-mode mass median diameters of organics were limited to the morning rush hour. Daytime particle concentration maxima of sulfate and nitrate in summer indicated substantial influence of photochemical processes, which also led to increments in mass median diameters in the accumulation mode thus inferring associated particle growth. Nocturnal nitrate formation was apparent in the accumulation mode in spring, concurring with the nighttime peak of ozone at the roadside, while in the Aitken mode, nitrate particle concentrations were significantly elevated during the dinner hours. Organics-related size distributions were mostly governed by intra-day changes at the urban site with very similar trends across different size distribution sets (i.e., concentration regimes), while disparities in diurnal variations among different size distribution sets were evident for nitrate and sulfate, particularly affecting the average sets, indicating stronger influence of irregular external factors, which were not associated with diurnal timescale processes.

Suburban particle size distributions exhibited variable diurnal characteristics, suggesting that irregular processes such as transport and seasonal meteorological conditions were the more dominant processes influencing particle size characteristics. Aitken-mode particle mass of organics was significantly larger in spring and summer, indicating greater influence of more local formation sources in the warm season. In the accumulation mode, organic particle mass concentrations were highest in fall and lowest in spring, following the frequency pattern of continental air mass influence. For sulfate, Aitken-mode mass concentrations peaked in the after- noon from spring throughout fall, with the highest nominal concentrations in spring and summer and the lowest levels in winter, while accumulation-mode particle mass was highest in summer and fall and lowest in winter, similar to the trend observed among organic constituents.

Nitrate particle mass in the Aitken mode was generally small in most seasons $\left(0.01-0.06 \mu \mathrm{g} \mathrm{m}^{-3}\right)$, except winter when daytime concentrations reached $\sim 0.1 \mu \mathrm{g} \mathrm{m}^{-3}$. In both modes, changes in mass median diameters varied temporally and in magnitude with seasons, indicating a stronger influence of specific meteorological conditions on the properties of nitrate-containing particles at the suburban site. At the urban site, periods of greater inorganic species mass concentrations were more likely to be caused by increases in both Aitken- and accumulation-mode particle mass in summer, indicating that particle formation and growth affecting smaller particles was more likely to occur in the warmer season. At the suburban receptor location, significant correlation of submode particle mass to total species concentration $\left(0.5 \leq R_{\mathrm{pr}} \leq 0.7\right)$ was observed for organics and nitrate in most seasons (spring, summer, winter), suggesting notable influence of local or regional formation processes on organic and nitrate Aitken-mode particulate mass. Variations in particle mixing state were examined with evaluation of interspecies MMD trends at both measurement sites. In the accumulation mode at the urban site, internal mixing appeared to be prevalent in spring, while greater frequency of time periods with external mixing of particle populations comprising different fractions of organic constituents was observed in summer. External mixing was predominant in the Aitken mode at the urban location in both seasons. At the suburban site, sulfate and nitrate in the accumulation mode more frequently exhibited differing particle size distributions in all seasons, signifying a greater extent of external mixing. In winter, it was evident that external mixing of more organics enriched particles in the lower accumulation size range.

Data availability. The data are available upon request. To obtain the data, please contact Chak K. Chan (chak.k.chan@cityu.edu.hk).

\section{The Supplement related to this article is available online at https://doi.org/10.5194/acp-17-13605-2017- supplement.}

Competing interests. The authors declare that they have no conflict of interest. 
Acknowledgements. This work was supported by the Environmental Conservation Fund of Hong Kong (project number ECWW09EG04). Chak K. Chan gratefully acknowledges the startup fund of the City University of Hong Kong.

Edited by: Eleanor Browne

Reviewed by: two anonymous referees

\section{References}

Abbatt, J. P. D., Broekhuizen, K., and Kumal, P. P.: Cloud condensation nucleus activity of internally mixed ammonium sulfate/organic acid aerosol particles, Atmos. Environ., 39, 47674778, https://doi.org/10.1016/j.atmosenv.2005.04.029, 2005.

Ahlquist, N. C. and Charlson, R. J.: A New Instrument for Evaluating the Visual Quality of Air, J. Air Pollut. Control Assoc., 17, 467-469, https://doi.org/10.1080/00022470.1967.10469006, 1967.

Aiken, A. C., Salcedo, D., Cubison, M. J., Huffman, J. A., DeCarlo, P. F., Ulbrich, I. M., Docherty, K. S., Sueper, D., Kimmel, J. R., Worsnop, D. R., Trimborn, A., Northway, M., Stone, E. A., Schauer, J. J., Volkamer, R. M., Fortner, E., de Foy, B., Wang, J., Laskin, A., Shutthanandan, V., Zheng, J., Zhang, R., Gaffney, J., Marley, N. A., Paredes-Miranda, G., Arnott, W. P., Molina, L. T., Sosa, G., and Jimenez, J. L.: Mexico City aerosol analysis during MILAGRO using high resolution aerosol mass spectrometry at the urban supersite (T0) - Part 1: Fine particle composition and organic source apportionment, Atmos. Chem. Phys., 9, 6633-6653, https://doi.org/10.5194/acp-9-6633-2009, 2009.

Bahreini, R., Dunlea, E. J., Matthew, B. M., Simons, C., Docherty, K. S., DeCarlo, P. F., Jimenez, J. L., Brock, C. A., and Middlebrook, A. M.: Design and operation of a pressure-controlled inlet for airborne sampling with an aerodynamic aerosol lens, Aerosol Sci. Tech., 42, 465-471, https://doi.org/10.1080/02786820802178514, 2008.

Bian, Q., Huang, X. H. H., and Yu, J. Z.: One-year observations of size distribution characteristics of major aerosol constituents at a coastal receptor site in Hong Kong - Part 1: Inorganic ions and oxalate, Atmos. Chem. Phys., 14, 9013-9027, https://doi.org/10.5194/acp-14-9013-2014, 2014.

Bohren, C. F. and Huffman, D. R.: Absorption and scattering of light by small particles, in: Absorption and Scattering of Light by Small Particles, Wiley-VCH Verlag GmbH, 1-11, 1983.

Canagaratna, M. R., Jayne, J. T., Jimenez, J. L., Allan, J. D., Alfarra, M. R., Zhang, Q., Onasch, T. B., Drewnick, F., Coe, H., Middlebrook, A., Delia, A., Williams, L. R., Trimborn, A. M., Northway, M. J., DeCarlo, P. F., Kolb, C. E., Davidovits, P., and Worsnop, D. R.: Chemical and microphysical characterization of ambient aerosols with the aerodyne aerosol mass spectrometer, Mass Spectrom. Rev., 26, 185-222, https://doi.org/10.1002/mas.20115, 2007.

Charlson, R. J., Langner, J., Rodhe, H., Leovy, C. B., and Warren, S. G.: Perturbation of the Northern-Hemisphere Radiative Balance by Backscattering from Anthropogenic Sulfate Aerosols, Tellus A, 43, 152-163, https://doi.org/10.1034/j.16000870.1991.00013.x, 1991.

Cheung, K., Ling, Z. H., Wang, D. W., Wang, Y., Guo, H., Lee, B., Li, Y. J., and Chan, C. K.: Characterization and source identification of sub-micron particles at the HKUST Supersite in Hong Kong, Sci. Total Environ., 527-528, 287-296, https://doi.org/10.1016/j.scitotenv.2015.04.087, 2015.

Crippa, M., DeCarlo, P. F., Slowik, J. G., Mohr, C., Heringa, M. F., Chirico, R., Poulain, L., Freutel, F., Sciare, J., Cozic, J., Di Marco, C. F., Elsasser, M., Nicolas, J. B., Marchand, N., Abidi, E., Wiedensohler, A., Drewnick, F., Schneider, J., Borrmann, S., Nemitz, E., Zimmermann, R., Jaffrezo, J.-L., Prévôt, A. S. $\mathrm{H}$., and Baltensperger, U.: Wintertime aerosol chemical composition and source apportionment of the organic fraction in the metropolitan area of Paris, Atmos. Chem. Phys., 13, 961-981, https://doi.org/10.5194/acp-13-961-2013, 2013.

Cross, E. S., Slowik, J. G., Davidovits, P., Allan, J. D., Worsnop, D. R., Jayne, J. T., Lewis, D. K., Canagaratna, M., and Onasch, T. B.: Laboratory and ambient particle density determinations using light scattering in conjunction with aerosol mass spectrometry, Aerosol Sci. Tech., 41, 343-359, https://doi.org/10.1080/02786820701199736, 2007.

Cross, E. S., Onasch, T. B., Canagaratna, M., Jayne, J. T., Kimmel, J., Yu, X.-Y., Alexander, M. L., Worsnop, D. R., and Davidovits, P.: Single particle characterization using a light scattering module coupled to a time-of-flight aerosol mass spectrometer, Atmos. Chem. Phys., 9, 7769-7793, https://doi.org/10.5194/acp-9-77692009, 2009.

Davidson, C. I., Phalen, R. F., and Solomon, P. A.: Airborne particulate matter and human health: A review, Aerosol Sci. Tech., 39 737-749, https://doi.org/10.1080/02786820500191348, 2005.

DeCarlo, P. F., Slowik, J. G., Worsnop, D. R., Davidovits, P., and Jimenez, J. L.: Particle morphology and density characterization by combined mobility and aerodynamic diameter measurements. Part 1: Theory, Aerosol Sci. Tech., 38, 1185-1205, https://doi.org/10.1080/027868290903907, 2004.

DeCarlo, P. F., Kimmel, J. R., Trimborn, A., Northway, M. J., Jayne, J. T., Aiken, A. C., Gonin, M., Fuhrer, K., Horvath, T., Docherty, K. S., Worsnop, D. R., and Jimenez, J. L.: Field-deployable, high-resolution, time-of-flight aerosol mass spectrometer, Anal. Chem., 78, 8281-8289, https://doi.org/10.1021/ac061249n, 2006.

Docherty, K. S., Aiken, A. C., Huffman, J. A., Ulbrich, I. M., DeCarlo, P. F., Sueper, D., Worsnop, D. R., Snyder, D. C., Peltier, R. E., Weber, R. J., Grover, B. D., Eatough, D. J., Williams, B. J., Goldstein, A. H., Ziemann, P. J., and Jimenez, J. L.: The 2005 Study of Organic Aerosols at Riverside (SOAR-1): instrumental intercomparisons and fine particle composition, Atmos. Chem. Phys., 11, 12387-12420, https://doi.org/10.5194/acp-11-123872011, 2011.

Docherty, K. S., Lewandowski, M., and Jimenez, J. L.: Effect of Vaporizer Temperature on Ambient Non-Refractory Submicron Aerosol Composition and Mass Spectra Measured by the Aerosol Mass Spectrometer, Aerosol Sci. Tech., 49, 485-494, https://doi.org/10.1080/02786826.2015.1042100, 2015.

Drewnick, F., Hings, S. S., DeCarlo, P., Jayne, J. T., Gonin, M., Fuhrer, K., Weimer, S., Jimenez, J. L., Demerjian, K. L., Borrmann, S., and Worsnop, D. R.: A new time-of-flight aerosol mass spectrometer (TOF-AMS) - Instrument description and first field deployment, Aerosol Sci. Tech., 39, 637-658, https://doi.org/10.1080/02786820500182040, 2005.

Elser, M., Huang, R.-J., Wolf, R., Slowik, J. G., Wang, Q., Canonaco, F., Li, G., Bozzetti, C., Daellenbach, K. R., Huang, 
Y., Zhang, R., Li, Z., Cao, J., Baltensperger, U., El-Haddad, I., and Prévôt, A. S. H.: New insights into $\mathrm{PM}_{2.5}$ chemical composition and sources in two major cities in China during extreme haze events using aerosol mass spectrometry, Atmos. Chem. Phys., 16, 3207-3225, https://doi.org/10.5194/acp-16-3207-2016, 2016.

Fang, C. P., McMurry, P. H., Marple, V. A., and Rubow, K. L.: Effect of Flow-induced Relative Humidity Changes on Size Cuts for Sulfuric Acid Droplets in the Microorifice Uniform Deposit Impactor (MOUDI), Aerosol Sci. Tech., 14, 266-277, https://doi.org/10.1080/02786829108959489, 1991.

Farmer, D. K., Matsunaga, A., Docherty, K. S., Surratt, J. D., Seinfeld, J. H., Ziemann, P. J., and Jimenez, J. L.: Response of an aerosol mass spectrometer to organonitrates and organosulfates and implications for atmospheric chemistry, P. Natl. Acad. Sci. USA, 107, 6670-6675, https://doi.org/10.1073/pnas.0912340107, 2010.

Fast, J., Aiken, A. C., Allan, J., Alexander, L., Campos, T., Canagaratna, M. R., Chapman, E., DeCarlo, P. F., de Foy, B., Gaffney, J., de Gouw, J., Doran, J. C., Emmons, L., Hodzic, A., Herndon, S. C., Huey, G., Jayne, J. T., Jimenez, J. L., Kleinman, L., Kuster, W., Marley, N., Russell, L., Ochoa, C., Onasch, T. B., Pekour, M., Song, C., Ulbrich, I. M., Warneke, C., Welsh-Bon, D., Wiedinmyer, C., Worsnop, D. R., Yu, X.-Y., and Zaveri, R.: Evaluating simulated primary anthropogenic and biomass burning organic aerosols during MILAGRO: implications for assessing treatments of secondary organic aerosols, Atmos. Chem. Phys., 9, 6191-6215, https://doi.org/10.5194/acp-9-6191-2009, 2009.

Gill, P. E., Murray, W., and Wright, M. H.: The LevenbergMarquardt method, in: Practical optimization, Academic Press, London, 1981.

Griffith, S. M., Huang, X. H. H., Louie, P. K. K., and Yu, J. Z.: Characterizing the thermodynamic and chemical composition factors controlling $\mathrm{PM}_{2.5}$ nitrate: Insights gained from two years of online measurements in Hong Kong, Atmos. Environ., 122, 864875, https://doi.org/10.1016/j.atmosenv.2015.02.009, 2015.

Guo, H., Wang, D. W., Cheung, K., Ling, Z. H., Chan, C. K., and Yao, X. H.: Observation of aerosol size distribution and new particle formation at a mountain site in subtropical Hong Kong, Atmos. Chem. Phys., 12, 9923-9939, https://doi.org/10.5194/acp12-9923-2012, 2012.

Huang, X.-F., He, L.-Y., Hu, M., Canagaratna, M. R., Sun, Y., Zhang, Q., Zhu, T., Xue, L., Zeng, L.-W., Liu, X.-G., Zhang, Y.-H., Jayne, J. T., Ng, N. L., and Worsnop, D. R.: Highly time-resolved chemical characterization of atmospheric submicron particles during 2008 Beijing Olympic Games using an Aerodyne High-Resolution Aerosol Mass Spectrometer, Atmos. Chem. Phys., 10, 8933-8945, https://doi.org/10.5194/acp-108933-2010, 2010.

Huang, X.-F., He, L.-Y., Hu, M., Canagaratna, M. R., Kroll, J. H., Ng, N. L., Zhang, Y.-H., Lin, Y., Xue, L., Sun, T.L., Liu, X.-G., Shao, M., Jayne, J. T., and Worsnop, D. R.: Characterization of submicron aerosols at a rural site in Pearl River Delta of China using an Aerodyne High-Resolution Aerosol Mass Spectrometer, Atmos. Chem. Phys., 11, 18651877, https://doi.org/10.5194/acp-11-1865-2011, 2011.

Huang, X. H. H., Bian, Q. J., Ng, W. M., Louie, P. K. K., and $\mathrm{Yu}$, J. Z.: Characterization of $\mathrm{PM}_{2.5}$ Major Components and Source Investigation in Suburban Hong Kong: A One
Year Monitoring Study, Aerosol Air Qual. Res., 14, 237-250, https://doi.org/10.4209/aaqr.2013.01.0020, 2014.

Huffman, J. A., Jayne, J. T., Drewnick, F., Aiken, A. C., Onasch, T., Worsnop, D. R., and Jimenez, J. L.: Design, modeling, optimization, and experimental tests of a particle beam width probe for the aerodyne aerosol mass spectrometer, Aerosol Sci. Tech., 39, 1143-1163, https://doi.org/10.1080/02786820500423782, 2005.

Jayne, J. T., Leard, D. C., Zhang, X. F., Davidovits, P., Smith, K. A., Kolb, C. E., and Worsnop, D. R.: Development of an aerosol mass spectrometer for size and composition analysis of submicron particles, Aerosol Sci. Tech., 33, 49-70, https://doi.org/10.1080/027868200410840, 2000.

Jimenez, J. L., Jayne, J. T., Shi, Q., Kolb, C. E., Worsnop, D. R., Yourshaw, I., Seinfeld, J. H., Flagan, R. C., Zhang, X. F., Smith, K. A., Morris, J. W., and Davidovits, P.: Ambient aerosol sampling using the Aerodyne Aerosol Mass Spectrometer, J. Geophys. Res.-Atmos., 108, 8425, https://doi.org/10.1029/2001jd001213, 2003.

John, W.: Size Distribution Characteristics of Aerosols, in: Aerosol Measurement, John Wiley \& Sons, Inc., 41-54, 2011.

Kerminen, V.-M., Paramonov, M., Anttila, T., Riipinen, I., Fountoukis, C., Korhonen, H., Asmi, E., Laakso, L., Lihavainen, H., Swietlicki, E., Svenningsson, B., Asmi, A., Pandis, S. N., Kulmala, M., and Petäjä, T.: Cloud condensation nuclei production associated with atmospheric nucleation: a synthesis based on existing literature and new results, Atmos. Chem. Phys., 12, 1203712059, https://doi.org/10.5194/acp-12-12037-2012, 2012.

Knote, C., Brunner, D., Vogel, H., Allan, J., Asmi, A., Äijälä, M., Carbone, S., van der Gon, H. D., Jimenez, J. L., Kiendler-Scharr, A., Mohr, C., Poulain, L., Prévôt, A. S. H., Swietlicki, E., and Vogel, B.: Towards an online-coupled chemistry-climate model: evaluation of trace gases and aerosols in COSMO-ART, Geosci. Model Dev., 4, 1077-1102, https://doi.org/10.5194/gmd-4-10772011, 2011.

Köhler, H.: The nucleus in and the growth of hygroscopic droplets, Trans. Faraday Soc., 32, 1152-1161, https://doi.org/10.1039/tf9363201152, 1936.

Lee, B. P., Li, Y. J., Yu, J. Z., Louie, P. K. K., and Chan, C. K.: Physical and chemical characterization of ambient aerosol by HR-ToF-AMS at a suburban site in Hong Kong during springtime 2011, J. Geophys. Res.-Atmos., 118, 8625-8639, https://doi.org/10.1002/jgrd.50658, 2013.

Lee, B. P., Li, Y. J., Yu, J. Z., Louie, P. K. K., and Chan, C. K.: Characteristics of submicron particulate matter at the urban roadside in downtown Hong Kong-Overview of 4 months of continuous high-resolution aerosol mass spectrometer measurements, J. Geophys. Res.-Atmos., 120, 7040-7058, https://doi.org/10.1002/2015jd023311, 2015.

Li, Y. J., Lee, B. Y. L., Yu, J. Z., Ng, N. L., and Chan, C. K.: Evaluating the degree of oxygenation of organic aerosol during foggy and hazy days in Hong Kong using high-resolution time-of-flight aerosol mass spectrometry (HR-ToF-AMS), Atmos. Chem. Phys., 13, 8739-8753, https://doi.org/10.5194/acp13-8739-2013, 2013.

Li, Y. J., Lee, B. P., Su, L., Fung, J. C. H., and Chan, C. K.: Seasonal characteristics of fine particulate matter (PM) based on highresolution time-of-flight aerosol mass spectrometric (HR-ToFAMS) measurements at the HKUST Supersite in Hong Kong, 
Atmos. Chem. Phys., 15, 37-53, https://doi.org/10.5194/acp-1537-2015, 2015.

Liu, P. S. K., Deng, R., Smith, K. A., Williams, L. R., Jayne, J. T., Canagaratna, M. R., Moore, K., Onasch, T. B., Worsnop, D. R., and Deshler, T.: Transmission efficiency of an aerodynamic focusing lens system: Comparison of model calculations and laboratory measurements for the Aerodyne Aerosol Mass Spectrometer, Aerosol Sci. Tech., 41, 721-733, https://doi.org/10.1080/02786820701422278, 2007.

Man, H., Zhu, Y., Ji, F., Yao, X., Lau, N. T., Li, Y., Lee, B. P., and Chan, C. K.: Comparison of daytime and nighttime new particle growth at the HKUST supersite in Hong Kong, Environ. Sci. Technol., 49, 7170-7178, https://doi.org/10.1021/acs.est.5b02143, 2015.

Meng, J. W., Yeung, M. C., Li, Y. J., Lee, B. Y. L., and Chan, C. K.: Size-resolved cloud condensation nuclei (CCN) activity and closure analysis at the HKUST Supersite in Hong Kong, Atmos. Chem. Phys., 14, 10267-10282, https://doi.org/10.5194/acp-1410267-2014, 2014.

Middlebrook, A. M., Bahreini, R., Jimenez, J. L., and Canagaratna, M. R.: Evaluation of Composition-Dependent Collection Efficiencies for the Aerodyne Aerosol Mass Spectrometer using Field Data, Aerosol Sci. Tech., 46, 258-271, https://doi.org/10.1080/02786826.2011.620041, 2012.

Mohr, C., DeCarlo, P. F., Heringa, M. F., Chirico, R., Slowik, J. G., Richter, R., Reche, C., Alastuey, A., Querol, X., Seco, R., Peñuelas, J., Jiménez, J. L., Crippa, M., Zimmermann, R., Baltensperger, U., and Prévôt, A. S. H.: Identification and quantification of organic aerosol from cooking and other sources in Barcelona using aerosol mass spectrometer data, Atmos. Chem. Phys., 12, 1649-1665, https://doi.org/10.5194/acp-121649-2012, 2012.

Quinn, P. K., Bates, T. S., Coffman, D., Onasch, T. B., Worsnop, D., Baynard, T., de Gouw, J. A., Goldan, P. D., Kuster, W. C., Williams, E., Roberts, J. M., Lerner, B., Stohl, A., Pettersson, A., and Lovejoy, E. R.: Impacts of sources and aging on submicrometer aerosol properties in the marine boundary layer across the Gulf of Maine, J. Geophys. Res.-Atmos., 111, D23S36, https://doi.org/10.1029/2006jd007582, 2006

Rupakheti, M., Leaitch, W. R., Lohmann, U., Hayden, K., Brickell, P., Lu, G., Li, S. M., Toom-Sauntry, D., Bottenheim, J. W., Brook, J. R., Vet, R., Jayne, J. T., and Worsnop, D. R.: An intensive study of the size and composition of submicron atmospheric aerosols at a rural site in Ontario, Canada, Aerosol Sci. Tech., 39, 722-736, https://doi.org/10.1080/02786820500182420, 2005.

Saarikoski, S., Carbone, S., Decesari, S., Giulianelli, L., Angelini, F., Canagaratna, M., Ng, N. L., Trimborn, A., Facchini, M. C., Fuzzi, S., Hillamo, R., and Worsnop, D.: Chemical characterization of springtime submicrometer aerosol in Po Valley, Italy, Atmos. Chem. Phys., 12, 8401-8421, https://doi.org/10.5194/acp12-8401-2012, 2012.

Salcedo, D., Onasch, T. B., Dzepina, K., Canagaratna, M. R., Zhang, Q., Huffman, J. A., DeCarlo, P. F., Jayne, J. T., Mortimer, P., Worsnop, D. R., Kolb, C. E., Johnson, K. S., Zuberi, B., Marr, L. C., Volkamer, R., Molina, L. T., Molina, M. J., Cardenas, B., Bernabé, R. M., Márquez, C., Gaffney, J. S., Marley, N. A., Laskin, A., Shutthanandan, V., Xie, Y., Brune, W., Lesher, R., Shirley, T., and Jimenez, J. L.: Characterization of ambient aerosols in Mexico City during the MCMA-2003 campaign with
Aerosol Mass Spectrometry: results from the CENICA Supersite, Atmos. Chem. Phys., 6, 925-946, https://doi.org/10.5194/acp-6925-2006, 2006.

Schwartz, S. E.: The Whitehouse effect - Shortwave radiative forcing of climate by anthropogenic aerosols: An overview, J. Aerosol Sci., 27, 359-382, https://doi.org/10.1016/00218502(95)00533-1, 1996.

Seinfeld, J. H. and Pandis, S. N.: Atmospheric Chemistry and Physics - From Air Pollution to Climate Change, 2nd Edn., John Wiley \& Sons, New Jersey, 2006.

Setyan, A., Zhang, Q., Merkel, M., Knighton, W. B., Sun, Y., Song, C., Shilling, J. E., Onasch, T. B., Herndon, S. C., Worsnop, D. R., Fast, J. D., Zaveri, R. A., Berg, L. K., Wiedensohler, A., Flowers, B. A., Dubey, M. K., and Subramanian, R.: Characterization of submicron particles influenced by mixed biogenic and anthropogenic emissions using high-resolution aerosol mass spectrometry: results from CARES, Atmos. Chem. Phys., 12, 8131-8156, https://doi.org/10.5194/acp-12-8131-2012, 2012.

Slowik, J. G., Stainken, K., Davidovits, P., Williams, L. R., Jayne, J. T., Kolb, C. E., Worsnop, D. R., Rudich, Y., DeCarlo, P. F., and Jimenez, J. L.: Particle morphology and density characterization by combined mobility and aerodynamic diameter measurements. Part 2: Application to combustion-generated soot aerosols as a function of fuel equivalence ratio, Aerosol Sci. Tech., 38, 12061222, https://doi.org/10.1080/027868290903916, 2004.

Sun, C., Lee, B. P., Huang, D., Jie Li, Y., Schurman, M. I., Louie, P. K. K., Luk, C., and Chan, C. K.: Continuous measurements at the urban roadside in an Asian megacity by Aerosol Chemical Speciation Monitor (ACSM): particulate matter characteristics during fall and winter seasons in Hong Kong, Atmos. Chem. Phys., 16, 1713-1728, https://doi.org/10.5194/acp-16-1713-2016, 2016.

Sun, Y., Zhang, Q., Macdonald, A. M., Hayden, K., Li, S. M., Liggio, J., Liu, P. S. K., Anlauf, K. G., Leaitch, W. R., Steffen, A., Cubison, M., Worsnop, D. R., van Donkelaar, A., and Martin, R. V.: Size-resolved aerosol chemistry on Whistler Mountain, Canada with a high-resolution aerosol mass spectrometer during INTEX-B, Atmos. Chem. Phys., 9, 3095-3111, https://doi.org/10.5194/acp-9-3095-2009, 2009.

Sun, Y.-L., Zhang, Q., Schwab, J. J., Demerjian, K. L., Chen, W.N., Bae, M.-S., Hung, H.-M., Hogrefe, O., Frank, B., Rattigan, O. V., and Lin, Y.-C.: Characterization of the sources and processes of organic and inorganic aerosols in New York city with a high-resolution time-of-flight aerosol mass apectrometer, Atmos. Chem. Phys., 11, 1581-1602, https://doi.org/10.5194/acp11-1581-2011, 2011.

Takegawa, N., Miyakawa, T., Watanabe, M., Kondo, Y., Miyazaki, Y., Han, S., Zhao, Y., van Pinxteren, D., Bruggemann, E., Gnauk, T., Herrmann, H., Xiao, R., Deng, Z., Hu, M., Zhu, T., and Zhang, Y.: Performance of an Aerodyne Aerosol Mass Spectrometer (AMS) during Intensive Campaigns in China in the Summer of 2006, Aerosol Sci. Tech., 43, 189-204, https://doi.org/10.1080/02786820802582251, 2009.

Ulbrich, I. M., Canagaratna, M. R., Zhang, Q., Worsnop, D. R., and Jimenez, J. L.: Interpretation of organic components from Positive Matrix Factorization of aerosol mass spectrometric data, Atmos. Chem. Phys., 9, 2891-2918, https://doi.org/10.5194/acp-92891-2009, 2009.

Ulbrich, I. M., Canagaratna, M. R., Cubison, M. J., Zhang, Q., Ng, N. L., Aiken, A. C., and Jimenez, J. L.: Three- 
dimensional factorization of size-resolved organic aerosol mass spectra from Mexico City, Atmos. Meas. Tech., 5, 195-224, https://doi.org/10.5194/amt-5-195-2012, 2012.

Westervelt, D. M., Pierce, J. R., Riipinen, I., Trivitayanurak, W., Hamed, A., Kulmala, M., Laaksonen, A., Decesari, S., and Adams, P. J.: Formation and growth of nucleated particles into cloud condensation nuclei: model-measurement comparison, Atmos. Chem. Phys., 13, 7645-7663, https://doi.org/10.5194/acp13-7645-2013, 2013.

Williams, L. R., Gonzalez, L. A., Peck, J., Trimborn, D., McInnis, J., Farrar, M. R., Moore, K. D., Jayne, J. T., Robinson, W. A., Lewis, D. K., Onasch, T. B., Canagaratna, M. R., Trimborn, A., Timko, M. T., Magoon, G., Deng, R., Tang, D., de la Rosa Blanco, E., Prévôt, A. S. H., Smith, K. A., and Worsnop, D. R.: Characterization of an aerodynamic lens for transmitting particles greater than 1 micrometer in diameter into the Aerodyne aerosol mass spectrometer, Atmos. Meas. Tech., 6, 3271-3280, https://doi.org/10.5194/amt-6-3271-2013, 2013.

Yao, X., Ling, T. Y., Fang, M., and Chan, C. K.: Size dependence of in situ $\mathrm{pH}$ in submicron atmospheric particles in Hong Kong, Atmos. Environ., 41, 382-393, https://doi.org/10.1016/j.atmosenv.2006.07.037, 2007a.

Yao, X. H., Lau, N. T., Chan, C. K., and Fang, M.: Size distributions and condensation growth of submicron particles in on-road vehicle plumes in Hong Kong, Atmos. Environ., 41, 3328-3338, https://doi.org/10.1016/j.atmosenv.2006.12.044, 2007 b.

Yuan, Z. B., Yadav, V., Turner, J. R., Louie, P. K. K., and Lau, A. K. H.: Long-term trends of ambient particulate matter emission source contributions and the accountability of control strategies in Hong Kong over 1998-2008, Atmos. Environ., 76, 21-31, https://doi.org/10.1016/j.atmosenv.2012.09.026, 2013.
Zhang, J. K., Sun, Y., Liu, Z. R., Ji, D. S., Hu, B., Liu, Q., and Wang, Y. S.: Characterization of submicron aerosols during a month of serious pollution in Beijing, 2013, Atmos. Chem. Phys., 14, 2887-2903, https://doi.org/10.5194/acp-14-2887-2014, 2014.

Zhang, Q., Stanier, C. O., Canagaratna, M. R., Jayne, J. T., Worsnop, D. R., Pandis, S. N., and Jimenez, J. L.: Insights into the chemistry of new particle formation and growth events in Pittsburgh based on aerosol mass spectrometry, Environ. Sci. Technol., 38, 4797-4809, https://doi.org/10.1021/es035417u, 2004.

Zhang, Q., Canagaratna, M. R., Jayne, J. T., Worsnop, D. R., and Jimenez, J. L.: Time- and size-resolved chemical composition of submicron particles in Pittsburgh: Implications for aerosol sources and processes, J. Geophys. Res.-Atmos., 110, D07S09, https://doi.org/10.1029/2004jd004649, 2005.

Zhang, Q., Jimenez, J. L., Canagaratna, M. R., Ulbrich, I. M., $\mathrm{Ng}$, N. L., Worsnop, D. R., and Sun, Y. L.: Understanding atmospheric organic aerosols via factor analysis of aerosol mass spectrometry: a review, Anal. Bioanal. Chem., 401, 3045-3067, https://doi.org/10.1007/s00216-011-5355-y, 2011.

Zheng, M., Kester, D. R., Wang, F., Shi, X. M., and Guo, Z. G.: Size distribution of organic and inorganic species in Hong Kong aerosols during the wet and dry seasons, J. Geophys. Res.Atmos., 113, D16303, https://doi.org/10.1029/2007jd009494, 2008.

Zhuang, H., Chan, C. K., Fang, M., and Wexler, A. S.: Size distributions of particulate sulfate, nitrate, and ammonium at a coastal site in Hong Kong, Atmos. Environ., 33, 843-853, https://doi.org/10.1016/S1352-2310(98)00305-7, 1999. 